Tjalling C. Koopmans Research Institute Tplligh Aoopman

Discussion Paper Series nr: 13-12

\title{
Imports and productivity: the impact of geography and factor intensity
}

Marcel van den Berg

Charles van Marrewijk 


\section{Tjalling C. Koopmans Research Institute Utrecht School of Economics Utrecht University}

Kriekenpitplein 21-22

3584 EC Utrecht

The Netherlands

telephone $\quad+31302539800$

fax +31302537373

website www.koopmansinstitute.uu.nl

The Tjalling C. Koopmans Institute is the research institute and research school of Utrecht School of Economics.

It was founded in 2003, and named after Professor Tjalling C. Koopmans, Dutch-born Nobel Prize laureate in economics of 1975.

In the discussion papers series the Koopmans Institute publishes results of ongoing research for early dissemination of research results, and to enhance discussion with colleagues.

Please send any comments and suggestions on the Koopmans institute, or this series to J.M.vanDort@uu.nl

ontwerp voorblad: WRIK Utrecht

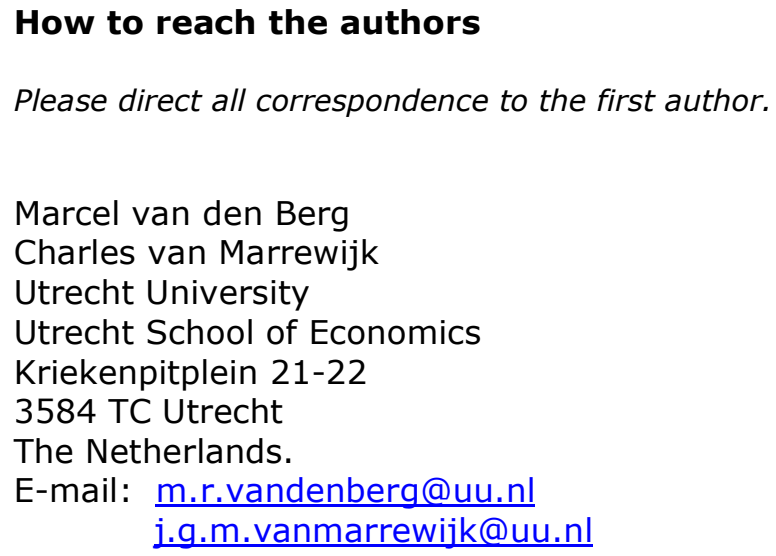


Utrecht School of Economics

Tjalling C. Koopmans Research Institute

Discussion Paper Series 13-12

\title{
Imports and productivity: the impact of geography and factor intensity
}

\author{
Marcel van den Berg \\ Charles van Marrewijk
}

Utrecht School of Economics

Utrecht University

September 2013

\begin{abstract}
Using micro-data for Dutch firms, we argue that the productivity spillovers from importing technology intensive products from Taiwan differ from importing unskilledlabor intensive products from Switzerland. We show that both the geographic component (what country is the import from) and the intensity component (what type of good is imported) is crucial for measuring and understanding these spillovers. We show that increasing distance and decreasing levels of development of the origin economy negatively affect the diffusion of efficiency gains embodied in imported goods. Similarly, these gains are larger for technology intensive goods and smaller for unskilled-labor intensive goods. This implies that the geographicintensity markets are unique and cannot be lumped together. In addition, a diversified import portfolio (the extensive dimension) is always positively associated with firm-level productivity.
\end{abstract}

Keywords: Firm heterogeneity, imports, productivity, geography, factor intensity

JEL classification: D22, F14, F23

\section{Acknowledgements}

This study is funded by the Ministry of Economic Affairs and the Ministry of Foreign Affairs of the Netherlands. We are grateful to Statistics Netherlands for providing us with the data underlying the analysis. We thank Marjolijn Jaarsma for her invaluable support in our comprehension of the various data sets. We also thank Peter van Bergeijk, Saara Tamminen, Emre Akgündüz, Fabienne Fortanier, René Bongard, Oscar Lemmers, Martin Luppes, Selwyn Moons, Bastiaan Rooijakkers and participants at the 2012 annual conference of the European Trade Study Group in Leuven, Belgium and the workshop 'Micro-evidence on labour market implications of globalization and agglomeration' of the CPB Netherlands Bureau for Economic Policy Analysis in The Hague, The Netherlands for valuable feedback and comments. Any remaining errors are our own. 


\section{Introduction}

The link between imports and productivity has been widely studied. There remains, however, a gap in this literature, namely the confusion between the impact of geographic versus goods characteristics on productivity at the firm level. This confusion is most clear in studies where all imports from advanced countries are (assumed) synonymous for high-technology imports (and all other imports by implication are low-technology imports), see for example Lööf and Andersson (2010); Castellani et al. (2010). We illustrate below (see figure 1) that this assumption is unwarranted and demonstrate in the remainder of this paper that the distinction is empirically important. As we are analyzing Dutch data, we will eventually be able to answer, from a Dutch firm's point of view, the question what is associated with higher firmlevel productivity? Importing (a) textiles (unskilled-labor intensive products) from Germany (a neighboring country), (b) cutlery (human-capital intensive products) from Italy (a Southern EU-15 country), or (c) tools (technology intensive products) from Tanzania (a developing country)?

The initial focus of the firm heterogeneity literature was on the relationship between firm productivity and export status. Later on the analysis also included the relationship between firm productivity and import status. In both cases firms engaging in international trade are larger, more productive, more capital intensive, pay higher wages, invest more in R\&D and have a higher probability of survival than domestic firms (see Wagner (2012) for a recent survey). Arguably, the channels through which import activities affect firm productivity are more direct than those for export activity, see the next section. It is therefore perhaps not surprising that Amiti and Konings (2007) find that the effect of a fall in import tariffs on productivity is at least twice as high as a fall in output tariffs. Our empirical analysis focuses on importing firms in The Netherlands.

Importing may raise productivity through learning, variety, and quality effects, for example for imported inputs. Three dimensions play a role, namely the geographical dimension (which country is the import from), the character of the good (what type of good is imported), and the extensive dimension (from how many countries and product markets is being imported). In the first two cases there are two sub-dimensions to consider. The geographical dimension may distinguish between advanced and developing countries or between proximate and remote countries. The character of the good may distinguish between intermediate and final goods or between types of goods based on (factor) intensity during the production process, such as technology intensive goods. Our data does not enable us to distinguish between intermediate and final goods, so regarding the goods characteristics we will focus 
attention on an intensity classification that identifies five different types of goods, namely primary, natural-resource intensive, unskilled-labor intensive, technology intensive, and human-capital intensive products. The extensive dimension of imports is relevant to consider, since the fixed cost of foreign (import) market entry may be market specific, which would imply that productivity needs to increase in the degree of diversity of the import portfolio.

Figure 1: Relationship between technology intensive imports and advanced country imports at the firm level (the Netherlands, 2002-2008, n=35,966)

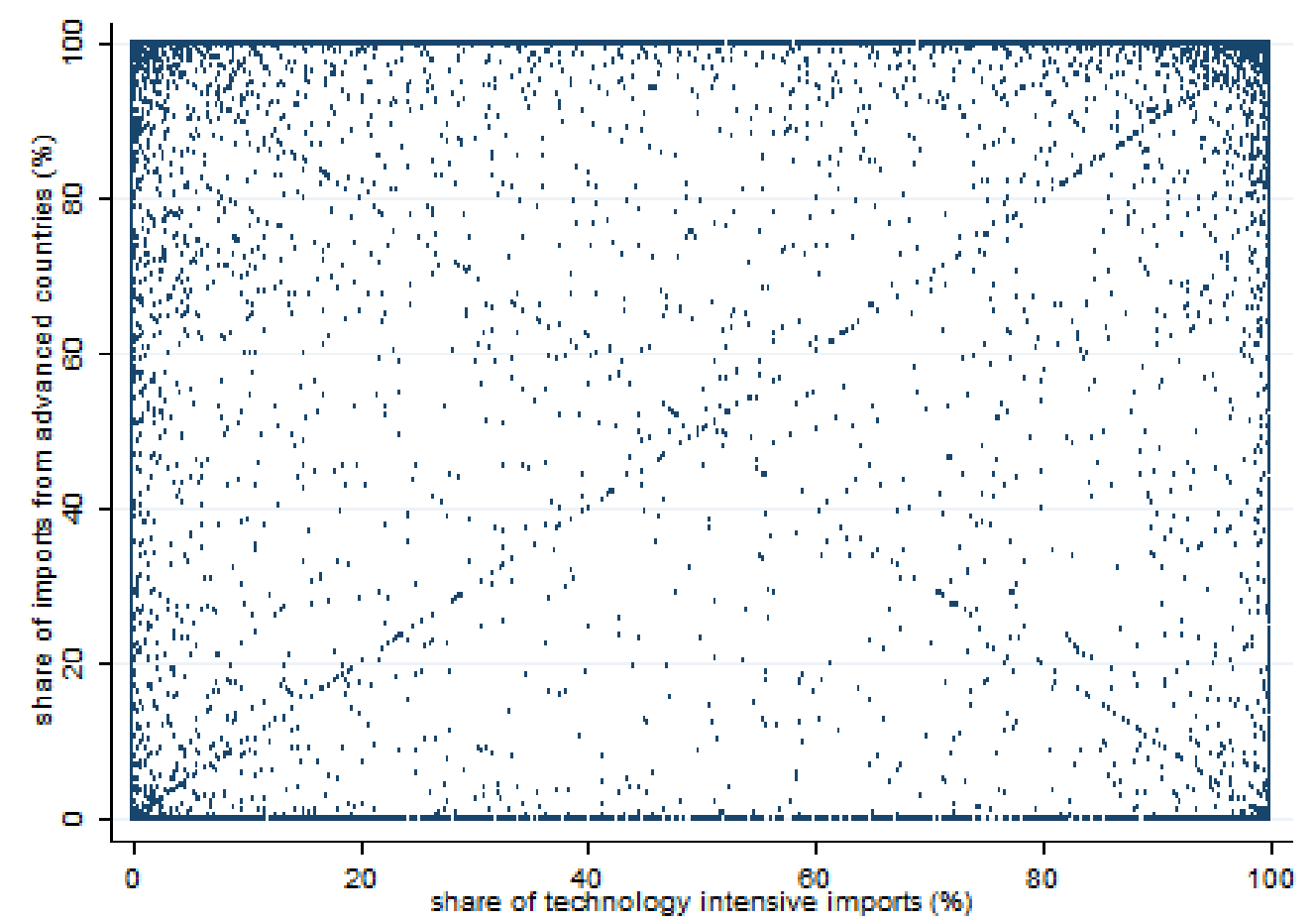

Notes: The share of imports from advanced economies is calculated as the share of imports from neighboring countries, Northern EU-15, Southern EU-15, non-EU Northwestern Europe, advanced Asia, Australia \& New Zealand and North America (see figure 5) in total imports of firms for which the full decomposition in terms of country of origin and factor intensity is known.

To illustrate that geography and intensity are really two different dimensions at the firm level, the scatter plot in figure 1 depicts technology intensive imports on the one hand and imports from advanced countries on the other hand for individual firms. If these two dimensions were more or less synonymous, as some of the literature assumes, there should be a strong positive association. In contrast, some firms import a lot from advanced countries, 
but these are not technology intensive products, while other firms import a lot of technology intensive products, but not from advanced countries. The objective of the paper, and our contribution to the literature, is therefore fourfold, namely to study the relationship between firm productivity and (i) the geographic dimension of imported goods (both advanced-developing and proximate-remote), (ii) the intensity dimension of imported goods, (iii) the geographic-intensity interaction and (iv) the degree of diversification of the import portfolio. Our results regarding the geographic-intensity interaction will determine, in particular, how harmful it is not to distinguish clearly between these two dimensions. An indication of this was already provided at the macroeconomic level by Coe et al. (1997) when they argued that developing countries can benefit from knowledge spillovers by importing from advanced countries through the interaction with machinery and equipment imports.

The remainder of the paper is organized as follows. Section 2 gives a brief overview of the empirical literature on the relationship between import status and firm performance regarding country of origin and factor intensity as explanatory factors. Section 3 discusses the Dutch data from the period 2002-2008 used in the empirical analysis. Section 4 gives an overview of the productivity characteristics of importers versus non-traders, exporters, and two-way traders. Section 5 analyzes firm productivity and the geographic dimensions of imports. Section 6 does the same regarding factor intensity. Section 7 analyzes firm productivity and geographic-intensity interaction. Section 8 concludes.

\section{Firm heterogeneity and imports}

The literature distinguishes several mechanisms through which importing and firm-level productivity could be causally related. Firms can raise productivity by importing R\&D intensive intermediate inputs from the technological frontier. Coe and Helpman (1995) and Coe et al. (1997) show empirically that productivity gains from $R \& D$ are indeed not only considerable in the source country, but that the benefits are also reaped by importing economies, both advanced and developing. Lööf and Andersson (2010) argue that global specialization plays a key role in enhancing firm productivity, since importing enables firms to utilize inputs from the technological frontier. Acharya and Keller (2009) present evidence on this matter suggesting that importing is an important vehicle for technology transfers between countries. Moreover, importing might offer firms the possibility to purchase intermediate inputs at lower cost. The wider variety of intermediate inputs that becomes avail- 
able through importing, amongst which higher quality inputs, can increase firm-level productivity. In addition to this, importing firms may benefit from spill-over effects and increase productivity by learning from foreign suppliers (Coe et al., 1997). This combination of learning and variety effects is also referred to as the complementarity aspect of importing. Finally, importing final goods increases competition on domestic markets, which forces domestic producers, regardless of their trading status, to operate more efficiently and thus become more productive (Amiti and Konings, 2007).

A considerable amount of firm level evidence suggests that firms importing inputs are more productive than firms that source inputs solely domestically. ${ }^{1}$ However, the empirical evidence regarding the impact of country of origin and factor intensity of imports on firm performance is much more scarce. Lööf and Andersson (2010) present evidence indicating that productivity increases in the share of imports from G7 countries. They conclude that imports are an important channel for technological learning and knowledge transfers, by assuming, rather crudely, that G7-imports are on average more R\&D and knowledge intensive and of better quality than imports from other countries. Serti and Tomasi (2009) and Castellani et al. (2010), employing a panel data set of Italian firms, investigate empirically whether the effect of trading on firm performance is related to geographic patterns of trade. Their findings indicate that imports from advanced economies are associated with a higher productivity premium than imports from developing economies. Their suggested explanation for this is that imports from highincome countries are presumably of higher quality and are more technology intensive than imports from lower income countries. These imports therefore require the presence of a certain amount of absorptive capacity which they associate with the existence of a productivity premium. The empirical evidence presented by Bas and Strauss-Kahn (2010) regarding French firms also suggest that the positive association between productivity and imports is stronger for imports from advanced economies. Silva et al. (2012) present empirical evidence regarding Portuguese firms, showing that geographical and sectoral diversification, for both imports and exports, is positively correlated with productivity. Furthermore, their findings indicate that trading with nearby and familiar economies is associated with a smaller productivity premium than trading in more 'difficult' markets.

A few general conclusions can be taken from the preceding discussion. A well-known stylized fact is that importers tend to be more productive and perform better in general than non-traders. The empirical evidence

\footnotetext{
${ }^{1}$ Among others see Bernard et al. (2007); Muûls and Pisu (2009); Vogel and Wagner (2010); Hagemejer and Kolasa (2011).
} 
regarding the impact of import characteristics in terms of geographical origin and factor intensity on firm performance is still rather scarce. However, the limited amount of evidence available on this matter indicates that imports from advanced countries or technologically advanced imports are associated with larger productivity premia.

\section{Data}

For the empirical analysis we merge data from three main Dutch data sources: (i) the General Business Register (GBR), (ii) the Baseline Database and (iii) the International Trade Database, all provided by Statistics Netherlands into a panel data set covering the years 2002 to $2008 .^{2}$ The data from the three different sources are merged using a unique identification number which is assigned by Statistics Netherlands to each individual firm in the General Business Register. The merging procedure is graphically depicted in figure $2 .^{3}$

The GBR is, in principle, exhaustive in the sense that it contains information about every firm in the Netherlands, including a set of basic firm characteristics such as the number of employees in fulltime equivalents, the sector in which the firm operates according to the internationally standardized ISIC Rev. 3.1 sector classification ${ }^{4}$ and some general address information. We take from a separate but related database information concerning the ultimate controlling institution of the firm, indicating whether the ultimate controlling owner of the Dutch firm is located abroad.

\footnotetext{
${ }^{2}$ We confine ourselves to discussing some key characteristics of each data source in this paper. For the details regarding the merging procedure see Van den Berg (2013).

${ }^{3}$ We focus the analysis in this paper on firms in manufacturing sectors and wholesale $\&$ retail trading sectors. This implies that typical service sectors are excluded. We choose financial intermediation as the cut-off point for service sectors, which corresponds to ISIC Rev. 3.1 section J, division 65. Manufacturing sectors correspond in the analysis to ISIC Rev. 3.1 sections A through I, excluding G. Wholesale \& retail traders correspond to ISIC Rev. 3.1 section $\mathrm{G}$ and service sectors, defined as sections J to Q, are excluded from the analysis. The OECD and Eurostat recommend to define manufacturing as sections A through $\mathrm{F}$ and to include section $\mathrm{G}$ to $\mathrm{Q}$ in services. However, in terms of goods trade this division is less sensible, since a considerable part of goods trade takes place in trade and transport sectors it is therefore more appropriate to separate these sections from typical (financial and public) service sectors.

${ }^{4}$ The ISIC Rev. 3.1 sector classification equals the SBI'93 2 digit classification employed by Statistics Netherlands
} 
Figure 2: Graphical representation of the merging steps towards a panel data set

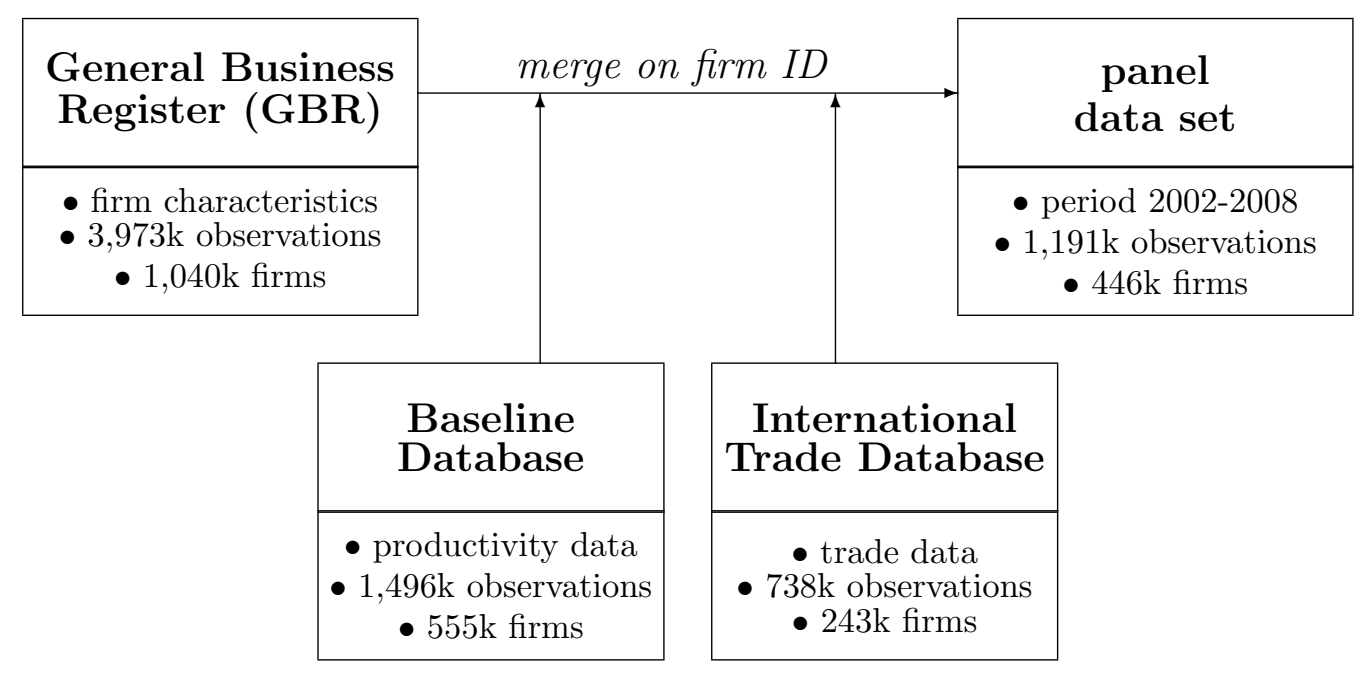

Data related to productivity measurement come from Baseline. This database contains a wealth of financial information collected from both corporate tax declarations and income tax declarations of entrepreneurs. Corporate tax declarations are registered on Value Added Tax (VAT) numbers, which need to be connected to the business identification numbers used by Statistics Netherlands. This match is only allowed when the connection is absolutely certain. Since firm structures tend to get more complex with increasing firm size, the success rate of the matching procedure decreases accordingly. Moreover, the Baseline data cover income tax statements of entrepreneurs only since 2006, the years 2002-2005 contain only data from corporate tax declarations. This implies that the annual number of observations in the panel increases considerably from 2006 onwards and the average firm size in the panel drops once income tax information is included. The information taken from the Baseline database is modified to fit the widely used KLEMS-framework, and contains information about gross output, value added and the value of capital, labor and intermediate inputs. ${ }^{5}$ The data regarding input used and output produced are deflated using separate sector level price indices for gross output, value added, labor, capital and intermediate inputs. We employ the data from tax declarations to calculate several different measures of productivity. Labor productivity (LP) is computed in

\footnotetext{
${ }^{5}$ The KLEMS-framework is an analytical framework in which data regarding input and output at the level of individual firms and industries are employed for growth and productivity analysis. One of the strengths of the KLEMS-framework is the international harmonization of the key concepts and methodologies
} 
two ways, as value added and gross output per employee deflated using a sector specific price index. We estimate total factor productivity (TFP) by employing the procedure proposed by Levinsohn and Petrin (2003). ${ }^{6}$

Trade data were taken from the International Trade database and includes information on all imports and exports of goods by Dutch firms. ${ }^{7}$ Extra-EU trade is recorded by the Customs Authority. These data always include product information at the 8-digit Combined Nomenclature (CN) level and specification of origin and destination country. Intra-EU imports and exports are recorded by the Dutch Tax Authority. Firms with intra-EU import and/or export values larger than a total of 900,000 euro (threshold in 2009) are required to specify their trade transactions at the 8-digit level according to the $\mathrm{CN}$ and specify the origin and destination of trade through an additional questionnaire from Statistics Netherlands. Below this threshold firms only need to report the total import and export value of intra-EU trade. The trade data available at the firm level cover more than $80 \%$ of annual aggregate trade in terms of value in the Netherlands. ${ }^{8}$ Finally, we also include import and export values according to the factor intensity of the goods traded, following Van Marrewijk (2002) and distinguishing between (i) primary products, (ii) natural resource intensive products, (iii) unskilled labor intensive products, (iv) high-tech products and (v) human capital intensive products. The merging procedure results in an unbalanced panel data set containing a total of 1.2 million observations of 446,000 manufacturing and wholesale \& retail trading firms spanning a period of seven years $(2002-2008) .^{9}$

\section{Main productivity characteristics}

Before we turn to the main research question of this paper, investigating how the characteristics of imports in terms of geographic origin and factor intensity affect firm-level productivity, we start by establishing whether importers outperform non-traders in terms of productivity, before turning to

\footnotetext{
${ }^{6}$ See Van den Berg (2013) for details regarding the estimation procedure.

${ }^{7}$ The trade data also include intra-firm trade, which cannot be distinguished from interfirm trade. Note also that apart from the import value we do not have information as to whether it concerns imports of capital goods, intermediate inputs or final goods.

${ }^{8}$ The trade data are recorded on VAT-numbers. Connection to the firm identification key used by Statistics Netherlands leads to a merging loss of about $20 \%$ of annual trade values.

${ }^{9}$ This is after eliminating micro firms (less than one fulltime equivalent) and implausible observations with zero or negative output or exports exceeding gross output. See Van den Berg (2013) for details.
} 
an empirical investigation of productivity differences within the subset of importers.

Figure 3: Firm-level productivity distribution by trade status (the Netherlands, 2002-2008)

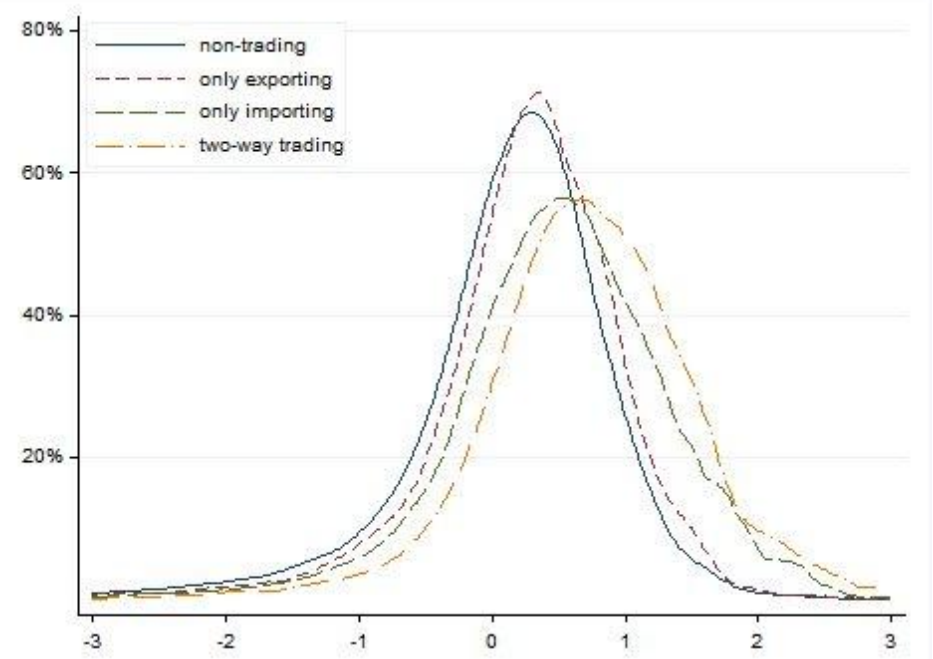

Notes: Following Melitz and Trefler (2012), the horizontal axis represents firm-level log of total factor productivity (TFP) scaled by subtracting the annual median productivity of the firm's 2-digit sector. The vertical axis represents the density of firms at that particular productivity level, weighted by firm size in terms of employment.

The complete distribution of firm-level total factor productivity by trade status, for manufacturing firms and wholesale \& retail trading firms pooled, is depicted in figure $3 .{ }^{10}$ The figure illustrates that the productivity distribution of non-traders is located left of the distributions of trading firms, followed by the productivity distributions of exporters, importers and twoway traders in that order from left to right. One way to consider the full distribution is to perform a series of Kolmogorov-Smirnov tests comparing the productivity distributions of non-traders, sole exporters, sole importers and two-way traders with each other. ${ }^{11}$ The results of the two-sided tests for both total factor productivity and labor productivity are significant in all cases, indicating that the productivity distributions of the four groups

\footnotetext{
${ }^{10}$ From this point onwards, the top and bottom $1 \%$ of the observations along the relevant productivity distribution are excluded, in order to eliminate implausible observations due to measurement errors, which we are unable to further investigate due to confidentiality considerations.

${ }^{11}$ See Girma et al. (2004) for a discussion of the Kolmogorov-Smirnov test.
} 
of firms do indeed differ. This holds for both manufacturing sectors and wholesale \& retail trading sectors.

The next step in the empirical analysis consists of estimating the trader premia, that is, the productivity difference between non-traders and traders that can be attributed to the differing trade status. In order to do so, we estimate the following empirical model:

$$
\begin{array}{r}
\ln \left(\operatorname{prod}_{i t}\right)=\alpha+\beta_{1} \text { importer }_{i t}+\beta_{2} \text { exporter }_{i t}+\beta_{3} \text { twowaytrader }_{i t} \\
+\beta_{4} \text { firmsize }_{i t}+\beta_{5} \text { foreigncontrolled }_{i t} \\
+\beta_{6} \text { year }_{t}+\beta_{7} \text { sector }_{i t}+\beta_{8} \text { region }_{i}+e_{i t}
\end{array}
$$

We estimate a pooled OLS-regression model employing the panel data concerning Dutch firms over the years 2002 to $2008 .{ }^{12}$ In this model the subscript $i$ identifies individual firms and $t$ indexes the year. The dependent variable to be estimated $\left(\ln \left(\operatorname{prod}_{i t}\right)\right)$ is either the natural log of total factor productivity, denoted by $\ln T F P_{i t}$, or the natural log of labor productivity, denoted by $\ln L P_{i t}$. Dummy variables regarding trade status, with nontrading firms as the reference group, are defined by importer $_{i t}$, exporter $_{i t}$ and twowaytrader $_{i t} .{ }^{13}$ We also include a series of control variables based on the preceding discussion; firm size in terms of employment in fulltime equivalents ( firmsize $_{i t}$ ), a dummy variable indicating whether the firm is controlled by a company located abroad foreigncontrolled $\left.{ }_{i t}\right)$ and a full set of year $\left(\right.$ year $\left._{t}\right)$, 2 -digit sector $\left(\right.$ sector $\left._{i t}\right)$ and region $\left(\right.$ region $\left._{i}\right)$ dummy variables. ${ }^{14}$ The region dummies identify the twelve Dutch provinces. ${ }^{15}$

Figure 4 shows the estimation results of the baseline model using TFP and LP as productivity measures. The ranking of sole exporters and sole

\footnotetext{
${ }^{12}$ In some studies in this strand of empirical literature firm fixed effects models are estimated next to pooled OLS-models. However, the trade status of individual firms is generally relatively stable. The panel consists of approximately 446,000 unique firms of which about 47,000 switch import status during the observed period, corresponding to less than 11 percent of the population. This implies that the individual firm-specific intercept would capture the better part of the effect of trade status on firm-level productivity for those firms where the trade status does not change during the observed period. This implies that the estimated coefficient only reflects the effect of trade status on productivity for those firms where the trade status changed during the observed time period, leading to biased estimates of the trade premia.

${ }^{13} \mathrm{~A}$ firm is considered being an exporter resp. importer in a particular year if it reports an export resp. import value larger than zero in that year.

${ }^{14}$ The dummy variable indicating whether a firm is ultimately controlled by a foreign company is not derived from the underlying ownership structure, it indicates whether the controlling institution is effectively located abroad.

${ }^{15}$ The Dutch provinces align with the second level of regional aggregation of the Nomenclature of Units for Territorial Statistics (NUTS2) developed by the European Union.
} 
importers is reversed compared to the productivity distributions depicted in figure 3, after controlling for additional firm characteristics. The trade premia are of considerable magnitude and statistically significant. Only importing firms are an estimated 12 percent more productive in terms of TFP and 22.8 percent in terms of labor productivity. ${ }^{16}$ Splitting the panel in typical manufacturing and wholesale \& retail trading sectors (see table 8 in the appendix) shows that the differences between both main sectors in terms of trade premia are limited. Wholesale \& retail traders show the highest productivity premium for both TFP and labor productivity of 14.5 resp. 25.4 percent, followed by manufacturers; 8 resp. 18.1 percent. In addition, we find a consistent productivity ordering for each subset, with non-traders being the least productive, followed by sole importers, sole exporters and twoway traders, in that order. The difference between the estimated coefficients of the distinguished trade statuses is statistically significant in the models including all firms and the separate subsets by main sector. This holds for for both total factor productivity and labor productivity. The coefficients of the control variables show the expected results.

Figure 4: Firm trade type and productivity, estimated coefficients (the Netherlands, 2002-2008)

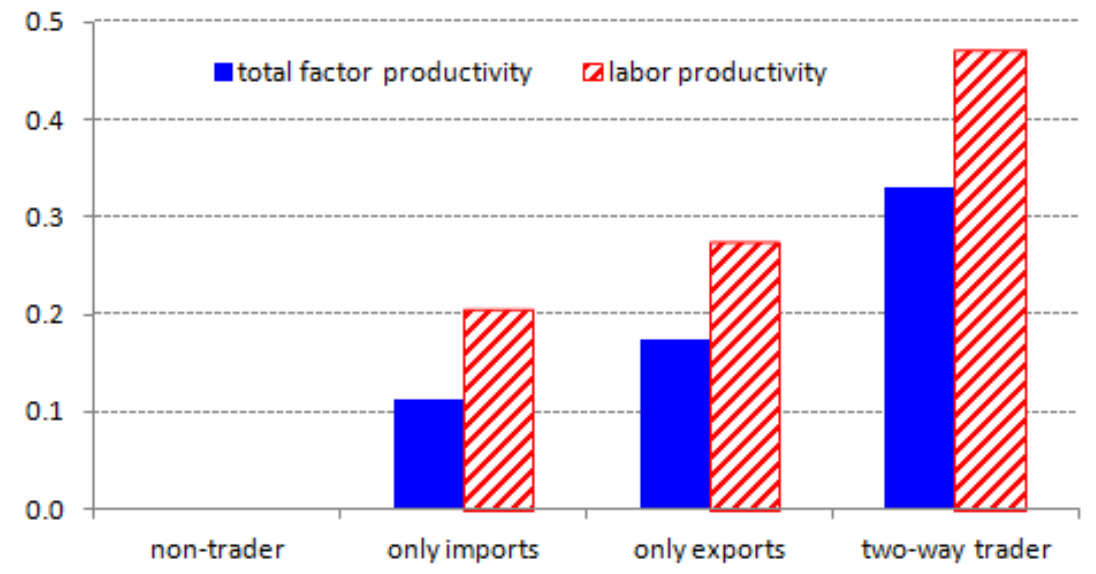

Note: All estimated trade premia are significant at the $0.1 \%$ level

\section{Does geographic origin of imports matter?}

Now we turn to the key part of the analysis; do the characteristics of imports affect firm-level productivity? We confine the analysis in this and the next

\footnotetext{
${ }^{16}$ Trade premia are calculated as $100(\exp (\beta)-1)$.
} 
sections to the subset of observations for which the complete breakdown of imports along the relevant dimensions is available. That is, we established in section 4 that importers are on average more productive than non-traders. In the following sections we focus on productivity differences within the subset of importers, conditional on being more productive on average than nontraders. ${ }^{17}$

To keep the analysis manageable we aggregate the import data by origin country into 13 mutually exclusive and exhaustive regions which are inspired by the geographical aggregation of countries by the World Bank; (1) neighboring countries, (2) Northern EU-15, (3) Southern EU-15, (4) nonEU Northwestern Europe, (5) the rest of the EU, (6) the rest of Europe, (7) Middle East \& North Africa, (8) sub-Sahara Africa, (9) developing Asia, (10) advanced Asia, (11) Australia \& New Zealand, (12) North America and (13) Latin America \& the Caribbean (see figure 5). ${ }^{18}$

Figure 5: Regional aggregation of origin countries

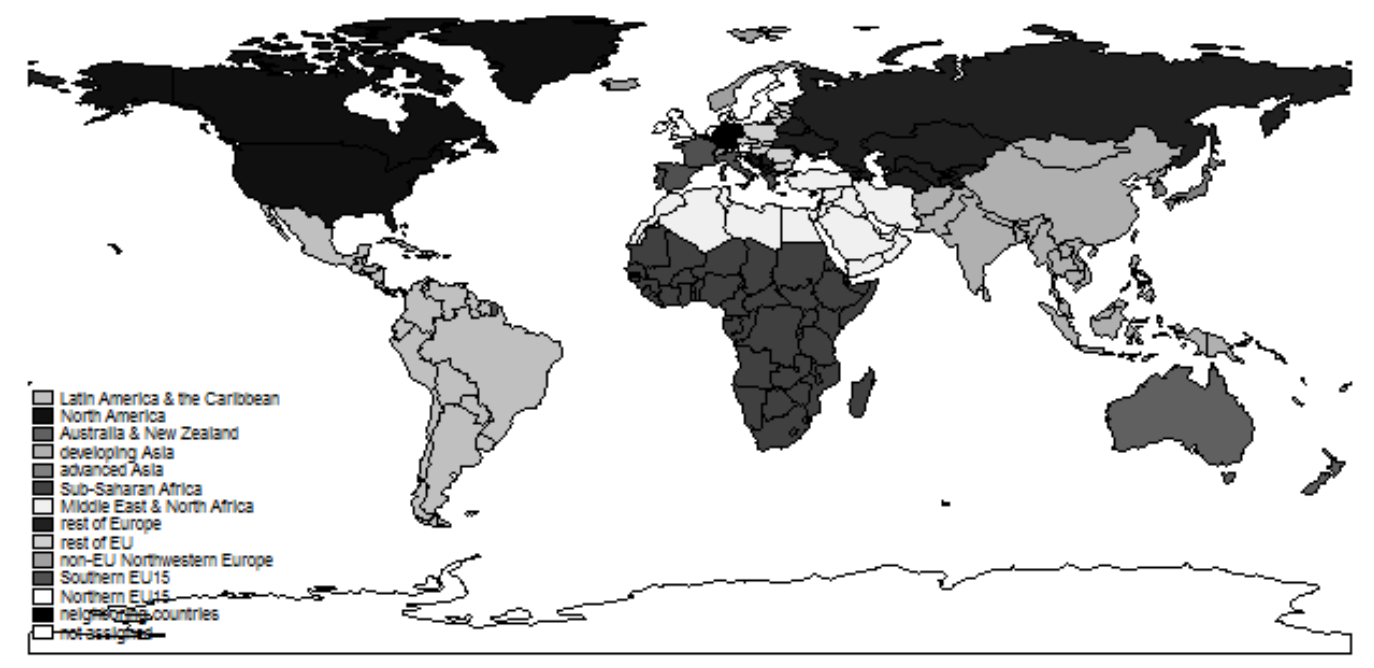

Table 1 shows for each of the identified regions the average productivity of firms that exclusively import from that region in a particular year. The table illustrates that firms exclusively importing from the EU-15 in general are on average considerably more productive than firms importing from regions further away. A distinct pattern does not emerge from the productivity dis-

\footnotetext{
${ }^{17}$ From this section onwards we only discuss empirical results using TFP as measure productivity, since the findings for labor productivity do not deviate to a noteworthy extent. The results using labor productivity as measure of productivity are available from the authors on request.

${ }^{18}$ The geographic regions are described in detail in table 9 in the appendix.
} 
tribution of the remaining regions, albeit that firms importing from advanced regions such as non-EU northwestern Europe, advanced Asia and Australia $\&$ New Zealand are at the top end.

Table 1: Productivity (TFP) by geographical import market

\begin{tabular}{|c|c|c|c|c|c|}
\hline regional market & no. of obs. & mean & regional market & no. of obs. & mean \\
\hline neighboring countries & 2,768 & 21,857 & Latin America and the Caribbean & 616 & 12,910 \\
\hline Northern EU-15 & 199 & 21,091 & rest of EU & 890 & 12,787 \\
\hline Southern EU-15 & 364 & 20,564 & rest of Europe & 423 & 12,496 \\
\hline non-EU Northwestern Europe & 1,927 & 15,050 & sub-Sahara Africa & 464 & 11,991 \\
\hline Australia and New Zealand & 309 & 13,692 & developing Asia & 6,180 & 10,892 \\
\hline advanced Asia & 1,726 & 13,629 & Middle East and North Africa & 1,749 & 10,735 \\
\hline \multirow[t]{3}{*}{ North America } & 6,542 & 12,974 & & & \\
\hline & & & non-tráding $\bar{x}$ & & $\overline{9} \overline{\overline{7}} \overline{2} \overline{3}$ \\
\hline & & & total & 24,157 & \\
\hline
\end{tabular}

Note: The calculations of the mean firm-level productivity by origin of imports are based on firms that import goods in a particular year exclusively from one single region.

Figure 6: TFP and \# of geographic import markets (left scale), \# of importers and \# of geographic import markets (right scale)

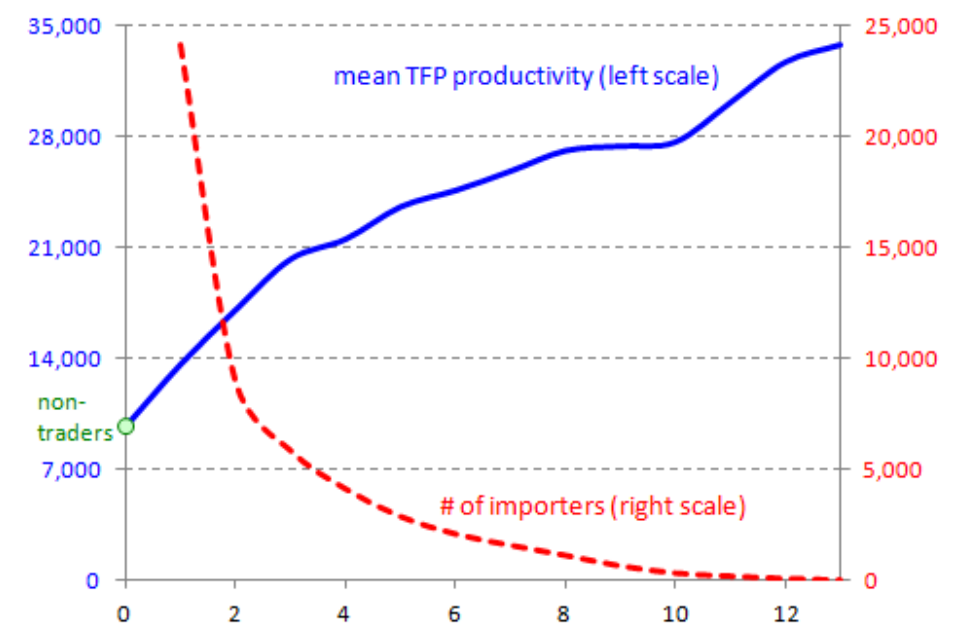

Figure 6 shows that more than half of the firms (observations) for which the complete geographical composition of imports is available sources inputs from more than one region. The number of observations monotonically decreases in the number of geographical import markets from $17 \%$ of the firms importing goods from two regions to $0.1 \%$ of the firms sourcing inputs from all (13) regions. Figure 6 also shows that productivity increases in the number of geographical markets the firm imports from. Mean productivity peaks at importing from the maximum of 13 geographical markets simultaneously. 
Particularly importing from a second, and to a lesser extent a third, geographical market seems to be associated with a considerable productivity premium. The productivity pattern emerging from Figure 6 points in the direction of the existence of fixed costs associated with importing from an additional geographical market. That is, not only import starters incur a fixed cost associated with the import start, but firms incur a fixed cost for each additional geographical market as well. However, the fixed cost of an import start still seem to be higher than the fixed cost of adding a geographical market to the import portfolio, considering the fact that mean productivity of non-traders is well below that of single market importers (see table 1).

The level of concentration of imports is generally high; $93 \%$ of the firms imports more than half of their goods exclusively from one region. This decreases to a still considerable $59 \%$ of the firms sourcing more than $95 \%$ of their imported goods from a single region. Moreover, concentration of imports is more persistent for regions far away than for regions nearby. In other words, firms importing goods from nearby are more likely to increase the number of regions they source goods from than firms importing from regions further away, indicating that distance is an important factor in the degree of concentration of imports. This suggests the existence of a stepping stone strategy regarding imports, where the firm starts importing from a country nearby and gradually expands its import activities to more distant markets in terms of both physical and cultural distance. This strategy regarding export market entry is well-documented, particularly regarding SMEs (see Creusen and Lejour (2011)). This observation is consistent with the hypothesis that fixed costs of importing from regions at great distance are higher than those of sourcing imported goods nearby.

We include the import shares of each of the regions of origin separately in the baseline regression model. Along with the import shares we include a measure of geographical dispersion of imports, namely the log of the number of regions from which a firm imports, as an explanatory variable. This brings us to the following to model to be estimated:

$$
\begin{aligned}
\ln \left(\text { prod }_{i t}\right)=\alpha & +\sum_{g=1}^{13} \beta_{g} \text { importshare }_{\text {git }}+\beta_{14} \text { dispersion }_{i t} \\
+\beta_{15} \text { twowaytrader }_{i t} & +\beta_{16} \text { firmsize }_{i t}+\beta_{17} \text { foreigncontrolled }_{i t} \\
& +\beta_{18} \text { year }_{t}+\beta_{19} \text { sector }_{i t}+\beta_{20} \text { region }_{i}+e_{i t}
\end{aligned}
$$

Each variable is defined in the same way as in equation $1 .^{19}$ In addition to

\footnotetext{
${ }^{19}$ Note that the analysis only contains firms that import by definition, implying that non-traders and sole exporters do not need to be accounted for.
} 
subscripts $i$ and $t$ identifying firms resp. years, subscript $g$ identifies geographic regions running from 1 to 13. We choose North America, accounting for the most observations, to serve as the reference group consistently throughout the analysis. The variable dispersion $i t$ is the log of the number of regional markets the firm imports from.

Figure 7: Estimated coefficients by geographic import market (Table 2, column 2)

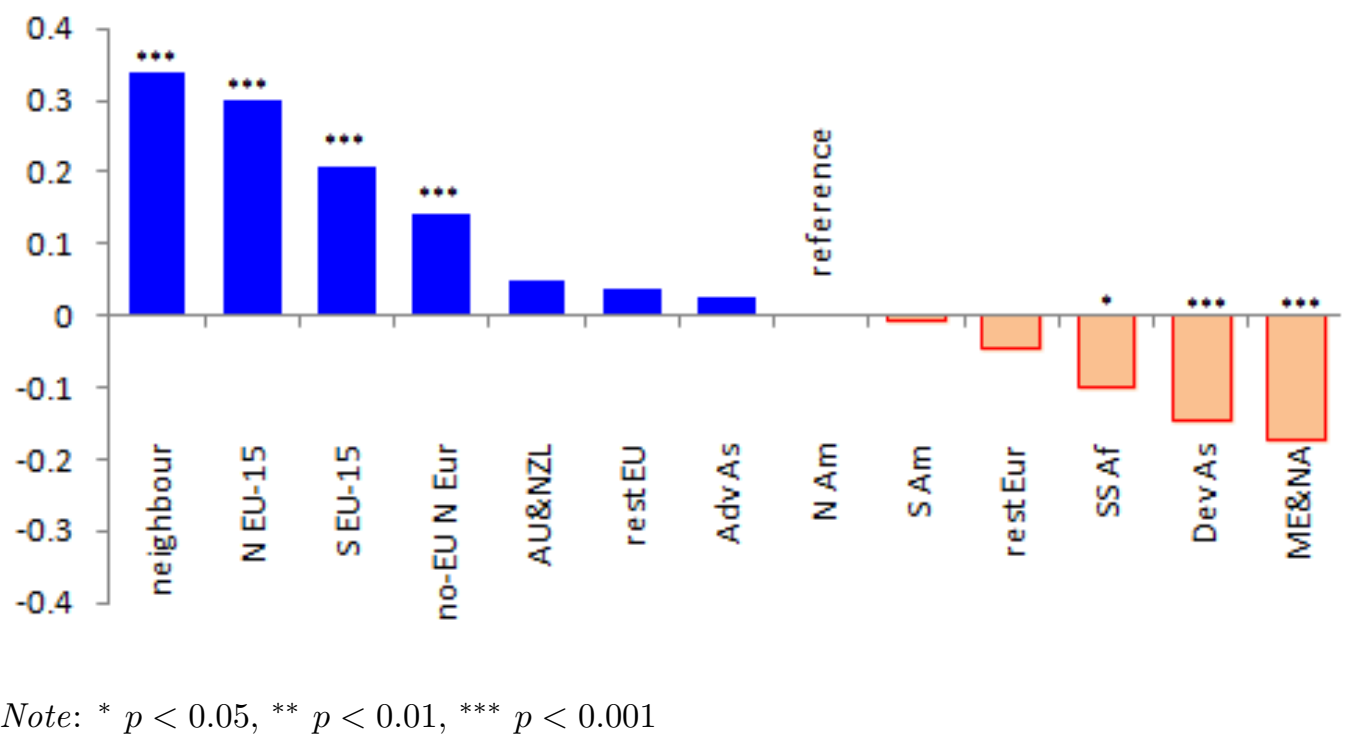

The results of these regressions are presented in table 2. The impact of the region of origin of imports on firm-level productivity could hypothetically go both ways; the importing firm can benefit from high quality imports from the technological frontier from advanced regions, located relatively nearby for Dutch firms, and thereby increase productivity. But the fixed and variable costs of importing are higher for imports from regions far away or from regions which pose more difficulties for Dutch importers due to various barriers to trade. This would imply that a higher level of productivity is needed to overcome those costs.

The regression results point in the direction of both mechanisms playing a role. The results indicate that higher import shares from regions nearby impact positively upon firm-level productivity (table 2, column 1). The estimated premia for imports from advanced regions nearby, neighboring countries, Northern and Southern EU-15 and non-EU Northwestern Europe are significantly positively correlated with firm-level productivity, relative to the reference region, which is North America. The differences between the premia estimated are considerable, with the premium of imports from Northern 
EU-15 being almost three times larger than the premium on imports from non-EU Northwestern Europe. In terms of distance, geographically, economically, culturally and linguistically, these regions contain the group of countries closest to the Netherlands. The import share from advanced regions further away (Australia \& New Zealand, the rest of the EU and advanced Asia) returns relatively small or insignificant productivity premia relative to North America, as does the import share from the rest of Europe and Latin America $\&$ the Caribbean. The import share from typical developing regions, such as sub-Saharan Africa, developing Asia and the Middle East \& North Africa, has a significantly negative impact on productivity.

Furthermore, a consistent picture emerges regarding the relationship between the degree of dispersion of imports and firm-level productivity; productivity increases in the number of regional import markets on which the firm sources its inputs (column 2). ${ }^{20}$ This finding seems in accordance with the theoretical argument stating that fixed costs of importing are market specific, and each additional market added to the import portfolio implies incurring these fixed cost again. Controlling for the degree of geographical dispersion does not impact heavily upon the estimated premia for the separate regions.

The control variables included in the regressions are all significant and consistently show the hypothesized sign. The separate regressions for manufacturing and wholesale \& retail trading sectors show that the estimated coefficients for import shares within the EU and Northwestern Europe are larger for wholesale \& retail traders. For imports from further away, the productivity premia for trading firms seem to decrease faster in physical distance than for manufacturing firms. Analogously, the productivity premium associated with a diversified import portfolio in geographical terms is higher for wholesale \& retail trading than for manufacturing firms. This taken together it seems that the pattern of productivity premia by geographic origin is more pronounced for firms in wholesale \& retail trading than for manufacturing firms.

\footnotetext{
${ }^{20}$ We also experimented with a Herfindahl-like measure of geographical concentration of imports. The findings corroborated the findings using the number of geographical markets as a measure of dispersion and are thus not reported separately for space considerations.
} 
Table 2: Import origin, degree of dispersion and total factor productivity (pooled OLS, 2002-2008)

\begin{tabular}{|c|c|c|c|c|c|c|}
\hline & \multicolumn{2}{|c|}{ all firms } & \multicolumn{2}{|c|}{$\begin{array}{l}\text { manufacturing } \\
\text { sectors }\end{array}$} & \multicolumn{2}{|c|}{$\begin{array}{l}\text { wholesale and } \\
\text { retail trading }\end{array}$} \\
\hline & (1) & $(2)$ & (3) & (4) & $(5)$ & $(6)$ \\
\hline \multicolumn{7}{|l|}{ import shares by geographic region } \\
\hline neighboring countries & $\begin{array}{c}0.361^{* * *} \\
(26.48)\end{array}$ & $\begin{array}{c}0.337^{* * *} \\
(24.61)\end{array}$ & $\begin{array}{c}0.278^{* * *} \\
(12.19)\end{array}$ & $\begin{array}{c}0.255^{* * *} \\
(11.12)\end{array}$ & $\begin{array}{c}0.372^{* * *} \\
(21.83)\end{array}$ & $\begin{array}{c}0.346^{* * *} \\
(20.30)\end{array}$ \\
\hline Northern EU15 & $\begin{array}{c}0.390^{* * *} \\
(19.93)\end{array}$ & $\begin{array}{c}0.300^{* * *} \\
(14.92)\end{array}$ & $\begin{array}{c}0.270^{* * *} \\
(7.13)\end{array}$ & $\begin{array}{c}0.208^{* * *} \\
(5.34)\end{array}$ & $\begin{array}{c}0.406^{* * *} \\
(17.48)\end{array}$ & $\begin{array}{c}0.300^{* * *} \\
(12.57)\end{array}$ \\
\hline Southern EU15 & $\begin{array}{c}0.283^{* * *} \\
(14.63)\end{array}$ & $\begin{array}{c}0.208^{* * *} \\
(10.50)\end{array}$ & $\begin{array}{c}0.161^{* * *} \\
(3.79)\end{array}$ & $\begin{array}{l}0.0913^{*} \\
(2.07)\end{array}$ & $\begin{array}{c}0.294^{* * *} \\
(13.15)\end{array}$ & $\begin{array}{c}0.213^{* * *} \\
(9.30)\end{array}$ \\
\hline non-EU Northwestern Europe & $\begin{array}{c}0.133^{* * *} \\
(7.04)\end{array}$ & $\begin{array}{c}0.140^{* * *} \\
(7.43)\end{array}$ & $\begin{array}{c}0.0976^{* * *} \\
(3.81)\end{array}$ & $\begin{array}{c}0.103^{* * *} \\
(4.03)\end{array}$ & $\begin{array}{c}0.150^{* * *} \\
(5.62)\end{array}$ & $\begin{array}{c}0.155^{* * *} \\
(5.82)\end{array}$ \\
\hline Australia and New Zealand & $\begin{array}{c}0.0576 \\
(1.31)\end{array}$ & $\begin{array}{c}0.0501 \\
(1.13)\end{array}$ & $\begin{array}{c}0.0785 \\
(1.29)\end{array}$ & $\begin{array}{l}0.0700 \\
(1.15)\end{array}$ & $\begin{array}{l}0.0396 \\
(0.66)\end{array}$ & $\begin{array}{c}0.0342 \\
(0.57)\end{array}$ \\
\hline rest of EU & $\begin{array}{c}0.0538^{*} \\
(2.02)\end{array}$ & $\begin{array}{l}0.0361 \\
(1.36)\end{array}$ & $\begin{array}{c}-0.0369 \\
(-0.91)\end{array}$ & $\begin{array}{l}-0.0507 \\
(-1.24)\end{array}$ & $\begin{array}{l}0.102^{* *} \\
(2.95)\end{array}$ & $\begin{array}{l}0.0819^{*} \\
(2.38)\end{array}$ \\
\hline advanced Asia & $\begin{array}{c}0.0489^{*} \\
(2.42)\end{array}$ & $\begin{array}{c}0.0259 \\
(1.28)\end{array}$ & $\begin{array}{c}0.0387 \\
(1.28)\end{array}$ & $\begin{array}{c}0.0271 \\
(0.90)\end{array}$ & $\begin{array}{c}0.0551^{*} \\
(2.10)\end{array}$ & $\begin{array}{c}0.0249 \\
(0.95)\end{array}$ \\
\hline North America & reference & reference & reference & reference & reference & reference \\
\hline Latin America and the Caribbean & $\begin{array}{c}0.00625 \\
(0.19)\end{array}$ & $\begin{array}{c}-0.00660 \\
(-0.20)\end{array}$ & $\begin{array}{c}0.0785 \\
(1.54)\end{array}$ & $\begin{array}{c}0.0614 \\
(1.21)\end{array}$ & $\begin{array}{c}-0.00886 \\
(-0.21)\end{array}$ & $\begin{array}{l}-0.0186 \\
(-0.45)\end{array}$ \\
\hline rest of Europe & $\begin{array}{c}-0.0361 \\
(-0.94)\end{array}$ & $\begin{array}{c}-0.0443 \\
(-1.16)\end{array}$ & $\begin{array}{c}0.0424 \\
(0.81)\end{array}$ & $\begin{array}{l}0.0347 \\
(0.67)\end{array}$ & $\begin{array}{c}-0.0899 \\
(-1.67)\end{array}$ & $\begin{array}{l}-0.0985 \\
(-1.84)\end{array}$ \\
\hline Sub-Sahara Africa & $\begin{array}{c}-0.0911^{*} \\
(-2.18)\end{array}$ & $\begin{array}{c}-0.0983^{*} \\
(-2.36)\end{array}$ & $\begin{array}{l}0.113^{*} \\
(2.00)\end{array}$ & $\begin{array}{l}0.103 \\
(1.82)\end{array}$ & $\begin{array}{c}-0.166^{* *} \\
(-3.12)\end{array}$ & $\begin{array}{c}-0.170^{* *} \\
(-3.21)\end{array}$ \\
\hline developing Asia & $\begin{array}{c}-0.139^{* * *} \\
(-9.42)\end{array}$ & $\begin{array}{c}-0.148^{* * *} \\
(-10.03)\end{array}$ & $\begin{array}{c}-0.0813^{* * *} \\
(-3.39)\end{array}$ & $\begin{array}{c}-0.0898^{* * *} \\
(-3.74)\end{array}$ & $\begin{array}{c}-0.150^{* * *} \\
(-8.11)\end{array}$ & $\begin{array}{c}-0.158^{* * *} \\
(-8.56)\end{array}$ \\
\hline Middle East and North Africa & $\begin{array}{c}-0.173^{* * *} \\
(-7.59)\end{array}$ & $\begin{array}{c}-0.175^{* * *} \\
(-7.68)\end{array}$ & $\begin{array}{c}-0.0863^{*} \\
(-2.25)\end{array}$ & $\begin{array}{c}-0.0877^{*} \\
(-2.29)\end{array}$ & $\begin{array}{c}-0.201^{* * *} \\
(-7.16)\end{array}$ & $\begin{array}{c}-0.202^{* * *} \\
(-7.22)\end{array}$ \\
\hline \multicolumn{7}{|c|}{ degree of geographical dispersion of imports } \\
\hline number of regional markets $(\log )$ & & $\begin{array}{c}0.102^{* * *} \\
(16.65)\end{array}$ & & $\begin{array}{c}0.0684^{* * *} \\
(6.39)\end{array}$ & & $\begin{array}{c}0.123^{* * *} \\
(16.46)\end{array}$ \\
\hline \multicolumn{7}{|l|}{ control variables } \\
\hline non-exporter & reference & reference & reference & reference & reference & reference \\
\hline exporter & $\begin{array}{l}0.208^{* * *} \\
(22.37)\end{array}$ & $\begin{array}{c}0.170^{* * *} \\
(17.61)\end{array}$ & $\begin{array}{c}0.161^{* * *} \\
(10.21)\end{array}$ & $\begin{array}{c}0.136^{* * *} \\
(8.23)\end{array}$ & $\begin{array}{c}0.231^{* * *} \\
(20.38)\end{array}$ & $\begin{array}{c}0.186^{* * *} \\
(15.81)\end{array}$ \\
\hline domestically controlled & reference & reference & reference & reference & reference & reference \\
\hline foreign controlled & $\begin{array}{c}0.164^{* * *} \\
(14.20)\end{array}$ & $\begin{array}{c}0.160^{* * *} \\
(13.84)\end{array}$ & $\begin{array}{c}0.0698^{* * *} \\
(3.78)\end{array}$ & $\begin{array}{c}0.0534^{* *} \\
(2.87)\end{array}$ & $\begin{array}{c}0.230^{* * *} \\
(15.70)\end{array}$ & $\begin{array}{c}0.240^{* * *} \\
(16.36)\end{array}$ \\
\hline firm size (fte, log) & $\begin{array}{c}0.197^{* * *} \\
(63.21)\end{array}$ & $\begin{array}{c}0.180^{* * *} \\
(55.07)\end{array}$ & $\begin{array}{c}0.184^{* * *} \\
(36.05)\end{array}$ & $\begin{array}{c}0.174^{* * *} \\
(32.50)\end{array}$ & $\begin{array}{c}0.206^{* * *} \\
(52.60)\end{array}$ & $\begin{array}{c}0.185^{* * *} \\
(44.96)\end{array}$ \\
\hline No. of observations & 52,397 & 52,397 & 15,519 & 15,519 & 36,878 & 36,878 \\
\hline$R^{2}$ & 0.266 & 0.269 & 0.277 & 0.279 & 0.262 & 0.266 \\
\hline
\end{tabular}


Summing up, the empirical results presented in this section show that a geographically diversified import portfolio is positively associated with firmlevel productivity. Furthermore, productivity premia associated with imports by geographic origin seem to decrease in distance and increase in the level of development of the origin economy. It seems plausible that these findings are related to the theoretical argument stating that fixed cost of importing are market specific, and each additional market added to the import portfolio implies incurring these fixed cost again. However, productivity hinges positively on concentration of imports within the EU-15. A possible explanation for this phenomenon could be that firms highly focused on imports from nearby countries are an integrated element of a value chain, enabling them to incur efficiency gains particularly by being focused in terms of their import portfolio. Furthermore, a partial explanation for the lack of empirical support for the hypothesis that the fixed and variable costs of importing are higher for imports from regions far away or from 'difficult' regions, could be provided by the nature of the products being imported from those regions. Imports from developing countries contain a relatively high fraction of final goods on average (possibly predestined for re-exporting), compared to imports from advanced countries (nearby) which contain a larger fraction of intermediate inputs. ${ }^{21}$ This is in line with Miroudot et al. (2009) showing that the bulk of intermediate goods trade takes place between advanced countries. In addition, Miroudot et al. (2009) show that trade between advanced and developing regions is characterized to a larger extent by final goods trade. It makes sense intuitively to expect that the potential for incurring productivity and efficiency gains is larger for intermediate goods imports than for imports of final goods or goods predestined for re-exporting. Unfortunately, it is neither possible at this point to separate between intermediate and final goods imports nor to identify the fraction of imports predestined for re-exporting. However, decomposing imports in terms of the factor intensity embodied in the goods being imported might shed further light on this issue.

\section{Does the factor intensity of imports mat- ter?}

Next to the geographic origin of imports we have information regarding the factor intensity of the imported goods, following the product classification

\footnotetext{
${ }^{21}$ Illustrative in this respect are back-of-the-envelope calculations indicating that about $60 \%$ of Dutch imports from China are destined for re-exporting, while this fraction is estimated to be about 30\% for imports from Belgium and Germany.
} 
developed by the International Trade Center into five types of product, see Van Marrewijk (2002).

i Primary products, such as meat, dairy, cereals, fruit, coffee, sand, minerals, oil, natural gas, iron ore, and copper ore.

ii Natural-resource intensive products, such as leather, cork, wood, lime, precious stones, pig iron, copper, aluminum, and lead.

iii Unskilled-labor intensive products, such as various textiles, clothing, glass, pottery, ships, furniture, footwear, and office supplies.

iv Technology intensive products, such as various chemicals, medicaments, plastics, engines, generators, machines, tools, pumps, telecommunications and photo equipment, optical equipment, and aircraft.

v Human-capital intensive products, such as synthetic colors, pigments, perfumes, cosmetics, rubber and tires, tubes, various types of steel and iron, cutlery, televisions, radio's, cars, watches, and jewelry.

We follow the same procedure as in section 5. Table 3 presents the mean productivity of firms that exclusively import products from one of the five distinguished product types. The table shows that mean productivity is highest for firms exclusively importing primary products and high-tech products. Unskilled labor intensive imports are associated with the lowest levels of productivity, although productivity of these firms is still higher on average than that of non-traders.

Table 3: Productivity (TFP) by intensity import market

\begin{tabular}{lrr}
\hline intensity market & no. of obs. & mean \\
\hline primary products & 2,751 & 17,671 \\
high-tech products & 5,305 & 16,287 \\
natural resource intensive & 759 & 14,378 \\
human capital intensive & 5,589 & 13,717 \\
unskilled labor intensive & 4,382 & 11,692 \\
\hline non-trading & & $9,72 \overline{3}$ \\
\hline total & 18,786 \\
\hline
\end{tabular}

Analogous to the number of geographical markets a firm imports from firm-level productivity increases in the number of international product markets the firm sources its inputs from (figure 8). Almost 60 percent of the 
firms imports goods exclusively from one class of products. This decreases rapidly to just under two percent of the firms importing from all five product groups. Firm-level productivity increases monotonically in the number of product markets, with TFP being almost twice as high for firms importing from all five product groups compared to firms importing from a single product group.

The level of concentration of imports is even higher for imports by factor intensity compared to imports by geographical origin; 98 percent of the firms sources more than half of its inputs from one product group, which decreases to 75 percent of the firms importing more than 95 percent of its total imports from a single product group. This is an intuitively straightforward observation, since the core business of the firm will most likely be the main determinant of the factor intensity of imports.

Figure 8: TFP and \# of intensity import markets (left scale), \# of importers and \# of intensity import markets (right scale)

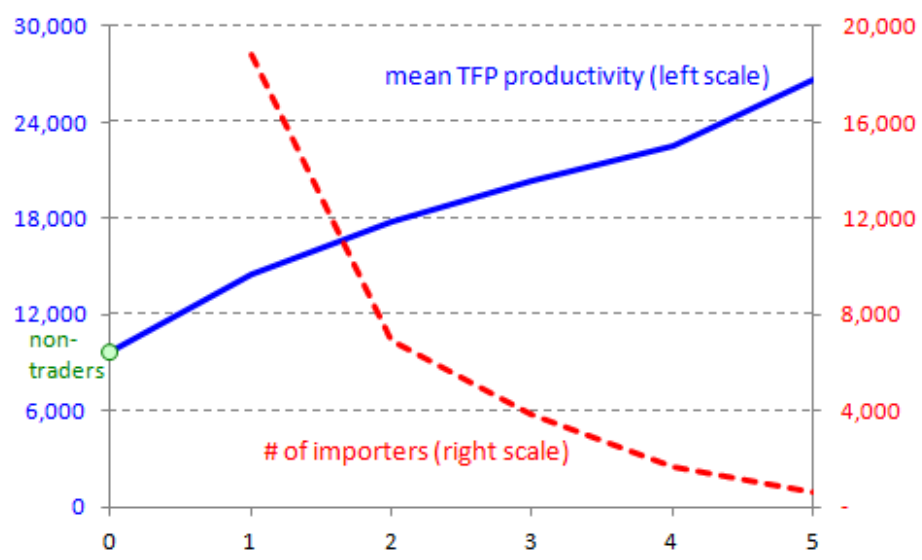

The import shares of the types of goods with different factor intensities are included separately in the baseline regression model along with a measure of the degree of dispersion of imports, which is defined as the (log of the) number of product markets on which the firm sources its inputs. Analogous to the procedure presented in section 5 we estimate the following model with import shares of each of the product groups by factor intensity as the explanatory variables of interest:

$$
\begin{array}{r}
\ln \left(\operatorname{prod}_{i t}\right)=\alpha+\sum_{f=1}^{5} \beta_{f} \text { importshare }_{\text {fit }}+\beta_{6} \text { dispersion }_{i t} \\
+\beta_{7} \text { twowaytrader }_{i t}+\beta_{8} \text { firmsize }_{i t}+\beta_{9} \text { foreigncontrolled }_{i t} \\
+\beta_{10} \text { year }_{t}+\beta_{11} \text { sector }_{i t}+\beta_{12} \text { region }_{i}+e_{i t}
\end{array}
$$


Where subscript $f$ identifies each of the five product classes, distinguished by their factor intensity and running from 1 to 5 .

In terms of import shares, importing high-tech products and primary products shows to be most beneficiary to firm-level productivity (figure 9). This makes sense intuitively, with the discussion of the mechanisms through which importing can raise productivity in mind (see section 2), especially with respect to technology intensive products. Following that same line of reasoning it is intuitively straightforward that importing mainly unskilled-labor intensive products impacts negatively upon firm-level productivity, which holds for both manufacturing and trading sectors.

Figure 9: Estimated coefficients by intensity import market (Table 4, column 2)

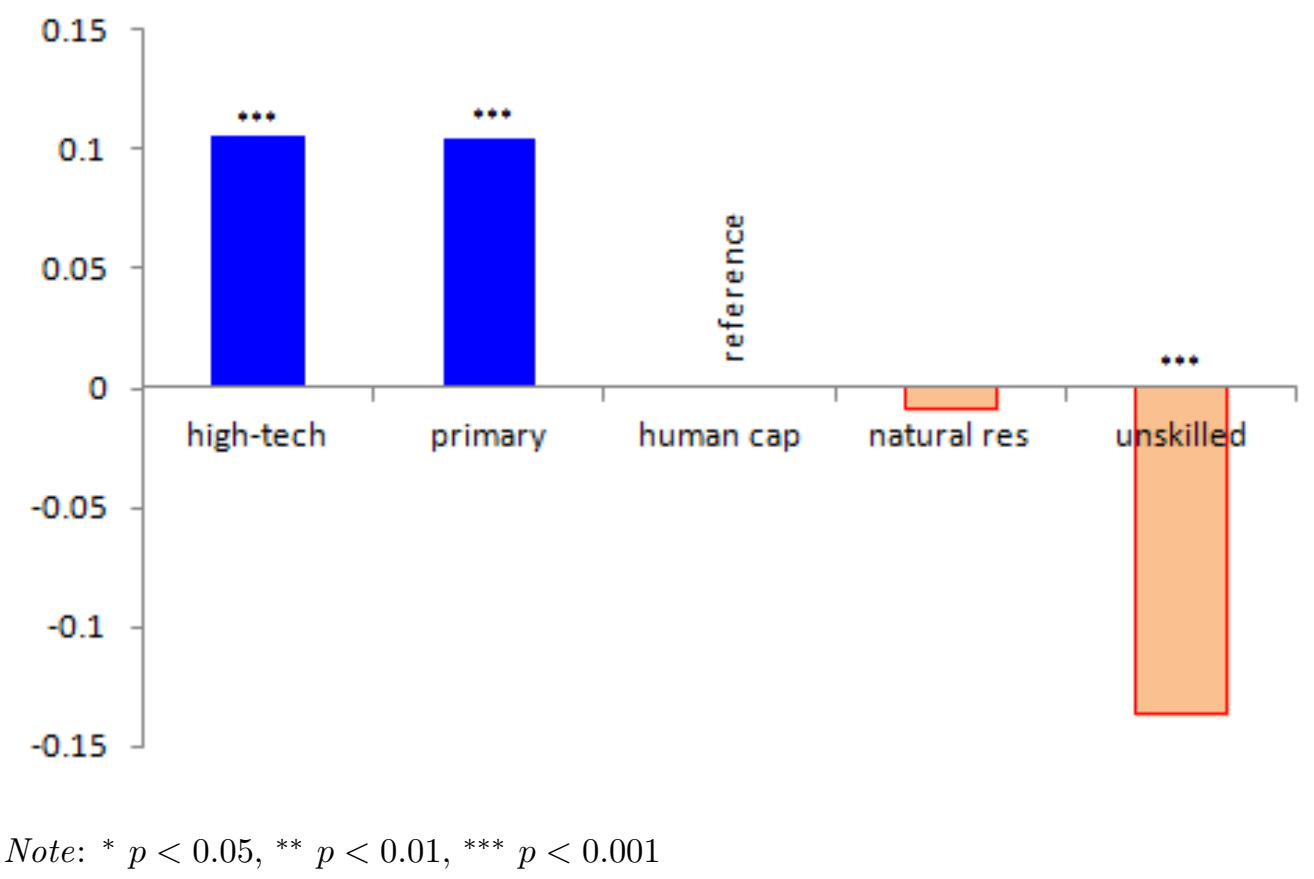

Note that the significantly positive association between productivity and primary and high-tech products is mainly on account of wholesale \& retail trading sectors, for which the pattern of estimated premia is more pronounced again (table 4). Natural-resource intensive goods return an insignificant coefficient relative to the reference group, which contains human capital intensive imports. Manufacturing sectors show a considerable number of insignificant coefficients, which is due to the relatively low number of observations, particularly for specific product groups. Furthermore, firm-level productivity is 
positively associated with the number of international product markets on which the firm is active. Again, all control variables included are significant and return the expected sign.

Table 4: Factor intensity of imports and total factor productivity (pooled OLS, 2002-2008)

\begin{tabular}{|c|c|c|c|c|c|c|}
\hline & \multicolumn{2}{|c|}{ all firms } & \multicolumn{2}{|c|}{$\begin{array}{l}\text { manufacturing } \\
\text { sectors }\end{array}$} & \multicolumn{2}{|c|}{$\begin{array}{l}\text { wholesale and } \\
\text { retail trading }\end{array}$} \\
\hline & $(1)$ & $(2)$ & $(3)$ & $(4)$ & $(5)$ & $(6)$ \\
\hline \multicolumn{7}{|l|}{ import shares by factor intensity } \\
\hline high-tech products & $\begin{array}{l}0.105^{* * *} \\
(7.24)\end{array}$ & $\begin{array}{c}0.106^{* * *} \\
(7.31)\end{array}$ & $\begin{array}{c}0.00537 \\
(0.25)\end{array}$ & $\begin{array}{c}0.00662 \\
(0.30)\end{array}$ & $\begin{array}{c}0.140^{* * *} \\
(7.50)\end{array}$ & $\begin{array}{c}0.140^{* * *} \\
(7.55)\end{array}$ \\
\hline primary products & $\begin{array}{c}0.0965^{* * *} \\
(5.12)\end{array}$ & $\begin{array}{c}0.104^{* * *} \\
(5.50)\end{array}$ & $\begin{array}{l}0.0522 \\
(1.47)\end{array}$ & $\begin{array}{l}0.0496 \\
(1.40)\end{array}$ & $\begin{array}{c}0.109^{* * *} \\
(4.93)\end{array}$ & $\begin{array}{c}0.121^{* * *} \\
(5.42)\end{array}$ \\
\hline natural resource intensive & $\begin{array}{c}0.00175 \\
(0.06)\end{array}$ & $\begin{array}{c}-0.00884 \\
(-0.32)\end{array}$ & $\begin{array}{l}0.0805 \\
(1.91)\end{array}$ & $\begin{array}{l}0.0723 \\
(1.71)\end{array}$ & $\begin{array}{c}-0.0242 \\
(-0.68)\end{array}$ & $\begin{array}{c}-0.0371 \\
(-1.04)\end{array}$ \\
\hline human capital intensive & reference & reference & reference & reference & reference & reference \\
\hline unskilled labor intensive & $\begin{array}{c}-0.136^{* * *} \\
(-8.32)\end{array}$ & $\begin{array}{c}-0.137^{* * *} \\
(-8.35)\end{array}$ & $\begin{array}{c}-0.0894^{* *} \\
(-3.01)\end{array}$ & $\begin{array}{c}-0.0924^{* *} \\
(-3.11)\end{array}$ & $\begin{array}{c}-0.135^{* * *} \\
(-6.89)\end{array}$ & $\begin{array}{c}-0.134^{* * *} \\
(-6.84)\end{array}$ \\
\hline \multicolumn{7}{|c|}{ degree of dispersion of imports by factor intensity } \\
\hline number of product markets $(\log )$ & & $\begin{array}{c}0.0546^{* * *} \\
(5.17)\end{array}$ & & $\begin{array}{c}0.0428^{*} \\
(2.40)\end{array}$ & & $\begin{array}{c}0.0659^{* * *} \\
(5.13)\end{array}$ \\
\hline \multicolumn{7}{|l|}{ control variables } \\
\hline non-exporter & reference & reference & reference & reference & reference & reference \\
\hline exporter & $\begin{array}{c}0.297^{* * *} \\
(25.91)\end{array}$ & $\begin{array}{c}0.288^{* * *} \\
(24.75)\end{array}$ & $\begin{array}{c}0.221^{* * *} \\
(11.98)\end{array}$ & $\begin{array}{c}0.212^{* * *} \\
(11.19)\end{array}$ & $\begin{array}{c}0.322^{* * *} \\
(22.75)\end{array}$ & $\begin{array}{c}0.313^{* * *} \\
(21.86)\end{array}$ \\
\hline domestically controlled & reference & reference & reference & reference & reference & reference \\
\hline foreign controlled & $\begin{array}{l}0.256^{* * *} \\
(14.97)\end{array}$ & $\begin{array}{c}0.246^{* * *} \\
(14.31)\end{array}$ & $\begin{array}{c}0.131^{* * *} \\
(4.88)\end{array}$ & $\begin{array}{c}0.120^{* * *} \\
(4.45)\end{array}$ & $\begin{array}{c}0.319^{* * *} \\
(14.78)\end{array}$ & $\begin{array}{c}0.310^{* * *} \\
(14.31)\end{array}$ \\
\hline firm size (FTE, log) & $\begin{array}{c}0.270^{* * * *} \\
(66.48) \\
\end{array}$ & $\begin{array}{c}0.266^{* * *} \\
(64.36) \\
\end{array}$ & $\begin{array}{c}0.221^{* * * *} \\
(34.77) \\
\end{array}$ & $\begin{array}{c}0.218^{* * *} \\
(33.26) \\
\end{array}$ & $\begin{array}{c}0.299^{* * *} \\
(57.04) \\
\end{array}$ & $\begin{array}{c}0.294^{* * *} \\
(55.37) \\
\end{array}$ \\
\hline No. of observations & 31,814 & 31,814 & 9,430 & 9,430 & 22,384 & 22,384 \\
\hline$R^{2}$ & 0.257 & 0.257 & 0.281 & 0.281 & 0.251 & 0.252 \\
\hline
\end{tabular}

\section{Interacting the geography and factor inten- sity of imports}

The analysis in the previous sections marks the build up to our ultimate goal; interacting the geographical origin and factor intensity of imports and investigate how the two-dimensional characteristics of imports affect firm- 
level productivity.

In order to keep the analysis manageable, we further aggregate the trade data by geographic origin and factor intensity into 18 two-dimensional productregion combinations, which we will denote geographical intensity markets. The decisions regarding aggregation are based on the level of significance of the difference between coefficient estimates of the regressions including import shares by region and product type. The bilateral $p$-values, resulting from a series of $t$-tests on the equality of estimated coefficients obtained from the regressions presented in tables 2 (column 2) and 4 (column 2), are depicted in tables 10 and 11 in the appendix. The results indicate that importing primary products and high-tech products does not significantly differ in terms of its impact on firm-level productivity. These product groups are thus aggregated into one group for the next step. The same holds for importing natural resource intensive products and human capital intensive products. Regarding the geographical dimension of imports we reduce the number of regions by aggregation from 13 to 6 . We pool together imports from neighboring countries and Northern EU-15. ${ }^{22}$ In addition, we also pool together other advanced countries (comprising of North America, advanced Asia and Australia \& New Zealand) and developing countries (pooled over developing Asia, Middle East \& North Africa and sub-Sahara Africa). Finally, imports from the rest of the EU (outside the EU-15), the rest of Europe and Latin America \& the Caribbean are taken together, forming a group we denote transition countries \& South America. This procedure leaves us with $6 \times 3=18$ mutually exclusive and exhaustive geographical intensity markets, comprising of 6 regions and 3 product groups.

Table 5 shows that the mean productivity of firms exclusively importing from the EU-15 is the highest, irrespective of the product type. In addition, productivity is consistently higher for firms exclusively importing from Northern EU-15 compared to Southern EU-15, followed by non-EU Northwestern Europe. Importing primary and high-tech products from advanced countries outside Europe is also associated with relatively high levels of productivity. Importing from developing countries is consistently associated with productivity levels at the lower end of the distribution. Within sourcing regions, importing primary and high-tech product is consistently associated with the highest productivity levels, followed by natural resource \& human capital intensive products. Exclusively importing unskilled labor intensive products is consistently associated with the lowest levels of productivity irrespective of

\footnotetext{
${ }^{22}$ Even though the $t$-test on the equality of the coefficients of these regions is just significant at the 5\%-level, we feel that the degree of European integration within these two regions and the degree of comparability and mutual dependency of the economies allows us to pool these two regions together.
} 
the sourcing region. Unskilled labor intensive imports from developing countries is associated with the lowest level of firm-level productivity, although the mean productivity of firms in this group is still (slightly) higher compared to non-traders.

Table 5: Productivity (TFP) by geographical intensity market

\begin{tabular}{|c|c|c|c|c|c|}
\hline geographical intensity market & $\begin{array}{l}\text { no. of } \\
\text { obs. }\end{array}$ & mean & geographical intensity market & $\begin{array}{l}\text { no. of } \\
\text { obs. }\end{array}$ & mean \\
\hline primary $\& 3$ high-tech products & & & unskilled labor intensive & & \\
\hline Northern EU-15 (incl. neighboring countries) & 804 & 23,066 & Northern EU-15 (incl. neighboring countries) & 226 & 19,656 \\
\hline Southern EU-15 & 104 & 20,896 & Southern EU-15 & 54 & 16,240 \\
\hline non-EU Northwestern Europe & 605 & 16,041 & non-EU Northwestern Europe & 182 & 12,420 \\
\hline other advanced countries & 2,364 & 14,177 & other advanced countries & 684 & 10,637 \\
\hline transition countries and South America & 542 & 13,113 & transition countries and South America & 339 & 10,918 \\
\hline developing countries & 1,618 & 12,497 & developing countries & 2,138 & 9,811 \\
\hline \multicolumn{6}{|l|}{ natural resource and human capital intensive } \\
\hline Northern EU-15 (incl. neighboring countries) & 699 & 20,814 & & & \\
\hline Southern EU-15 & 68 & 19,779 & & & \\
\hline non-EU Northwestern Europe & 540 & 13,399 & & & \\
\hline other advanced countries & 2,234 & 11,794 & & & \\
\hline transition countries and South America & 393 & 13,172 & & & \\
\hline \multirow[t]{3}{*}{ developing countries } & 1,482 & 10,594 & & & \\
\hline & & & non-trading & & $\overline{9} \overline{\overline{2}} \overline{3} \overline{3}$ \\
\hline & & & total & 15,076 & \\
\hline
\end{tabular}

None of the firms in the panel sources inputs from all 18 geographical intensity markets; the largest number of markets on which a firm is active is 17. Productivity increases monotonously in the number of markets on which the firm sources its inputs. Comparable to the picture emerging from figure 6 it seems that adding a second, third and fourth geographical intensity market to the import portfolio is particularly associated with a productivity threshold, which points in the direction of the existence of fixed costs associated with importing from an additional geographical intensity market. The degree of concentration of imports in geographical intensity markets is high with 96 percent of the firms sourcing the majority of its imports on a single market. This decreases to a still considerable 63 percent of the firms importing more than 95 percent of its total import value exclusively from a single two-dimensional market.

Analogous to the proceedings in the previous sections we include the import shares of each of the 18 geographical intensity markets in the baseline regression model, in addition to the log of the number of two-dimensional import markets on which the firm is active, as a measure of import dispersion. 
This leads to the following regression model to be estimated:

$$
\begin{aligned}
\ln \left(\text { prod }_{i t}\right)= & +\sum_{h=1}^{18} \beta_{h} \text { importshare }_{\text {hit }}+\beta_{19} \text { dispersion }_{i t} \\
+\beta_{20} \text { twowaytrader }_{i t} & +\beta_{21} \text { firmsize }_{i t}+\beta_{22} \text { foreigncontrolled }_{i t} \\
& +\beta_{23} \text { year }_{t}+\beta_{24} \text { sector }_{i t}+\beta_{25} \text { region }_{i}+e_{i t}
\end{aligned}
$$

Subscript $h$ identifies each of the geographical intensity markets running from 1 to 18 . Each variable is defined in the same way as in equation 2 . We choose to exclude the most prominent geographical intensity market to serve as the reference group, which is primary \& high-tech imports from advanced countries outside Europe.

The result of these regressions is presented in table 6 , the significance of the bilateral differences between estimated productivity premia is presented in table 7 . In order to gain an understanding of the importance of including the interaction between geographic origin and factor intensity of imports we also present the regressions with both dimensions separately without interaction term. Comparing the results from the three separate regressions we see that controlling for both dimension simultaneously is important, since the estimated premia for both dimensions separately show to be additive nor multiplicative. The geographic-intensity markets are largely unique and cannot be lumped together: no less than 119 out of 144 possible combinations (or 83 per cent of all combinations) are statistically significantly different at the 10 per cent level, while 116 (or 81 per cent) are statistically significantly different at the 5 per cent level.

Importing from the EU-15 in general is most positively associated with productivity at the firm-level, with Northern EU-15 returning consistently larger coefficients than Southern EU-15. Relative to the reference group the coefficient for all three product groups are significantly positive, with the impact of primary \& high-tech product being the largest, before, in that order, natural resource intensive \& human capital intensive imports and unskilled labor intensive imports. Compared to the reference group, imports from all three product groups from non-EU Northwestern Europe show a small, significant and positive productivity premium. The same holds for imports from transition countries \& South America, except for unskilled labor intensive imports. The dispersion within imports from other advanced countries is considerable. With human capital \& natural resource intensive imports representing the reference group we find high-tech and primary products returning a significant positive productivity premium and unskilled labor intensive imports a significant negative premium. Finally, the estimated coefficients 
are negative and significant for human capital \& natural resource intensive and unskilled labor intensive imports from developing regions.

The results thus indicate that the productivity premium of importing generally increases in the import share of nearby and advanced regions. Within regions, productivity decreases in the share of unskilled labor intensive imports, although in relative terms, importing goods from this group from the nearby regions still correlates relatively positively with productivity. In addition, the measure of dispersion of imports shows that productivity increases in the number of geographical intensity markets on which the firm is active. Finally, the control variables perform well in the sense that they are all significant and show the expected sign.

The separate regressions for manufacturing and wholesale \& retail trading sectors (table 12 in the appendix) show that the results regarding the full sample are mainly driven by wholesale \& retail trading sectors, which we thus do not discuss separately. The separate regressions for manufacturing sectors yield relatively many insignificant coefficients, which is due to the small numbers of observations underlying some of the distinguished geographical intensity markets. Relative to the reference group, importing from Northern EU-15 shows significant productivity premia for all three product groups. In addition, importing all but human capital \& natural resource intensive imports from non-EU Northwestern Europe and human capital \& natural resource intensive products from Southern EU-15 and transition countries \& South America is associated with a productivity premium. Unskilled labor intensive imports from developing countries yield a negative productivity premium. Finally, productivity significantly increases in the number of import markets on which the manufacturing firms is active. 
Table 6: Import origin, factor intensity, degree of dispersion and total factor productivity (pooled OLS, 2002-2008)

\begin{tabular}{|c|c|c|c|c|c|c|}
\hline & (1) & $(2)$ & (3) & (4) & (5) & (6) \\
\hline \multicolumn{7}{|l|}{ import shares by geographic import market } \\
\hline Northern EU-15 (incl. neighboring countries) & $0.418^{* * *}$ & & & $0.394^{* * *}$ & & \\
\hline Southern EU-15 & $0.351^{* * *}$ & & & $0.290^{* * *}$ & & \\
\hline non-EU Northwestern Europe & $0.128^{* * *}$ & & & $0.130^{* * *}$ & & \\
\hline transition countries \& South America & 0.0212 & & & 0.00858 & & \\
\hline other advanced countries & reference & & & reference & & \\
\hline developing countries & $-0.143^{* * *}$ & & & $-0.143^{* * *}$ & & \\
\hline \multicolumn{7}{|l|}{ import shares by intensity market } \\
\hline high-tech \& primary products & & $0.104^{* * *}$ & & & $0.107^{* * *}$ & \\
\hline human capital and natural resource intensive & & reference & & & reference & \\
\hline unskilled labor intensive & & $-0.125^{* * *}$ & & & $-0.127^{* * *}$ & \\
\hline \multicolumn{7}{|l|}{ import shares by geographic intensity market } \\
\hline \multicolumn{7}{|l|}{ Northern EU15 incl. neighboring countries } \\
\hline high-tech \& primary products & & & $0.510^{* * *}$ & & & $0.489^{* * *}$ \\
\hline human capital \& natural resource intensive & & & $0.473^{* * *}$ & & & $0.459^{* * *}$ \\
\hline unskilled labor intensive & & & $0.407^{* * *}$ & & & $0.384^{* * *}$ \\
\hline \multicolumn{7}{|l|}{ Southern EU15 } \\
\hline high-tech \& primary products & & & $0.452^{* * *}$ & & & $0.414^{* * *}$ \\
\hline human capital \& natural resource intensive & & & $0.453^{* * *}$ & & & $0.406^{* * *}$ \\
\hline unskilled labor intensive & & & $0.295^{* * *}$ & & & $0.264^{* * *}$ \\
\hline \multicolumn{7}{|l|}{ non-EU Northwestern Europe } \\
\hline high-tech \& primary products & & & $0.230^{* * *}$ & & & $0.237^{* * *}$ \\
\hline human capital \& natural resource intensive & & & $0.140^{* * *}$ & & & $0.144^{* * *}$ \\
\hline unskilled labor intensive & & & $0.141^{*}$ & & & $0.146^{* *}$ \\
\hline \multicolumn{7}{|l|}{ transition countries 85 South America } \\
\hline high-tech \& primary products & & & $0.117^{* *}$ & & & $0.110^{* *}$ \\
\hline human capital \& natural resource intensive & & & $0.119^{* *}$ & & & $0.114^{* *}$ \\
\hline unskilled labor intensive & & & -0.0492 & & & -0.0561 \\
\hline \multicolumn{7}{|l|}{ other advanced countries } \\
\hline high-tech \& primary products & & & $0.153^{* * *}$ & & & $0.154^{* * *}$ \\
\hline human capital \& natural resource intensive & & & reference & & & reference \\
\hline unskilled labor intensive & & & $-0.139^{* * *}$ & & & $-0.147^{* * *}$ \\
\hline \multicolumn{7}{|l|}{ developing countries } \\
\hline high-tech \& primary products & & & 0.0170 & & & 0.0140 \\
\hline human capital \& natural resource intensive & & & $-0.128^{* * *}$ & & & $-0.136^{* * *}$ \\
\hline $\begin{array}{c}\text { unskilled labor intensive } \\
\text { degree of dispersion of imports }\end{array}$ & & & $-0.151^{* * *}$ & & & $-0.153^{* * *}$ \\
\hline number of geographic markets $(\log )$ & & & & $0.102^{* * *}$ & & \\
\hline number of intensity markets $(\log )$ & & & & & $0.0635^{* * *}$ & \\
\hline number of geographic intensity markets (log) & & & & & & $0.0688^{* * *}$ \\
\hline \multicolumn{7}{|l|}{ control variables } \\
\hline non-exporter & reference & reference & reference & reference & reference & reference \\
\hline exporter & $0.204^{* * *}$ & $0.287^{* * *}$ & $0.193^{* * *}$ & $0.183^{* * *}$ & $0.280^{* * *}$ & $0.175^{* * *}$ \\
\hline domestically controlled & reference & reference & reference & reference & reference & reference \\
\hline foreign controlled & $0.223^{* * *}$ & $0.286^{* * *}$ & $0.219^{* * *}$ & $0.217^{* * *}$ & $0.276^{* * *}$ & $0.207^{* * *}$ \\
\hline firm size (FTE, log) & $0.227^{* * *}$ & $0.274^{* * *}$ & $0.225^{* * *}$ & $0.219^{* * *}$ & $0.271^{* * * *}$ & $0.218^{* * *}$ \\
\hline No. of observations & 29,878 & 29,878 & 29,878 & 29,878 & 29,878 & 29,878 \\
\hline$R^{2}$ & 0.269 & 0.246 & 0.273 & 0.270 & 0.246 & 0.274 \\
\hline
\end{tabular}


Table 7: Overview of bilateral significance of geographic-intensity productivity premia (table 6 , column 6 )

\begin{tabular}{|c|c|c|c|c|c|c|c|c|c|c|c|c|c|c|c|c|c|c|c|}
\hline & & $\mathrm{A}$ & A & A & B & B & B & $\mathrm{C}$ & C & $\mathrm{C}$ & D & $\mathrm{D}$ & D & $\mathrm{E}$ & $\mathrm{E}$ & $\mathrm{E}$ & $F$ & $\mathrm{~F}$ & $\mathrm{~F}$ \\
\hline & & 1 & 2 & 3 & 1 & 2 & 3 & 1 & 2 & 3 & 1 & 2 & 3 & 1 & 2 & 3 & 1 & 2 & 3 \\
\hline $\mathrm{A}$ & 1 & - & & & & & & & & & 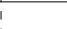 & & & & & & 1 & & \\
\hline A & 2 & 0.18 & - & & & & & & & & $\begin{array}{l}\text { ! } \\
\vdots\end{array}$ & & & & & & ! & & \\
\hline A & 3 & 0.00 & 0.02 & - & & & & & & & & & & & & & & & \\
\hline $\bar{B}$ & $-\overline{1}$ & $\overline{0} . \overline{0} \overline{4}$ & $\overline{0} . \overline{2} \overline{3}$ & $\overline{0} . \overline{5} \overline{0}$ & - & & & & & & & & & & & & & & \\
\hline B & 2 & 0.06 & 0.27 & 0.67 & 0.89 & - & & & & & 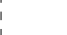 & & & & & & 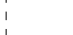 & & \\
\hline B & 3 & 0.00 & 0.00 & 0.04 & 0.01 & 0.03 & - & & & & & & & & & & 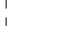 & & \\
\hline $\bar{C}$ & $-\overline{1}$ & $\overline{0} . \overline{0} \overline{0}$ & $\overline{0} . \overline{0}$ & $\overline{0} . \overline{0}$ & 0.00 & 0.00 & $\overline{0.65}$ & - & & & I & & & & & & 1 & & \\
\hline $\mathrm{C}$ & 2 & 0.00 & 0.00 & 0.00 & 0.00 & 0.00 & 0.05 & 0.03 & - & & ! & & & & & & 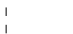 & & \\
\hline $\mathrm{C}$ & 3 & 0.00 & 0.00 & 0.00 & 0.00 & 0.00 & 0.11 & 0.13 & 0.97 & - & & & & & & & & & \\
\hline$\overline{\mathrm{D}}$ & $-\overline{1}$ & $\overline{0} . \overline{0} \overline{0}$ & $\overline{0} . \overline{0} \overline{0}$ & $\overline{0} . \overline{0} \overline{0}$ & 0.00 & 0.00 & $\overline{0.01}$ & 0.00 & $\overline{0 . \overline{4}} \overline{-}$ & $\overline{0.56}$ & - & & & & & & & & \\
\hline D & 2 & 0.00 & 0.00 & 0.00 & 0.00 & 0.00 & 0.02 & 0.01 & 0.55 & 0.62 & 0.94 & - & & & & & 1 & & \\
\hline D & 3 & 0.00 & 0.00 & 0.00 & 0.00 & 0.00 & 0.00 & 0.00 & 0.00 & 0.00 & $\begin{array}{l}0.00 \\
\end{array}$ & 0.00 & - & & & & & & \\
\hline $\bar{E}$ & $-\overline{1}$ & 0.00 & 0.00 & 0.00 & 0.00 & 0.00 & 0.04 & 0.01 & $0 . \overline{78}$ & $0 . \overline{8} 9$ & $0 . \overline{2} \overline{0}$ & $0 . \overline{3} \overline{4}$ & 0.00 & $\overline{-}$ & & & & & \\
\hline $\mathrm{E}$ & 2 & 0.00 & 0.00 & 0.00 & 0.00 & 0.00 & 0.00 & 0.00 & 0.00 & 0.01 & $\begin{array}{l}0.00 \\
\end{array}$ & 0.01 & 0.23 & 0.00 & - & & & & \\
\hline $\mathrm{E}$ & 3 & 0.00 & 0.00 & 0.00 & 0.00 & 0.00 & 0.00 & 0.00 & 0.00 & 0.00 & 0.00 & 0.00 & 0.09 & 0.00 & 0.00 & - & & & \\
\hline$\overline{\mathrm{F}}$ & $-\overline{1}$ & $\overline{0} . \overline{0} \overline{0}$ & $\overline{0} . \overline{0} \overline{0}$ & $\overline{0} . \overline{0} \overline{0}$ & 0.00 & 0.00 & $\overline{0.00}$ & 0.00 & 0.00 & $\overline{0} \overline{0} 2$ & $\overline{0} . \overline{0} \overline{2}$ & $\overline{0} . \overline{0} \overline{2}$ & $\overline{0} . \overline{1} \overline{4}$ & 0.00 & 0.59 & $\overline{0.00}$ & - & & \\
\hline $\mathrm{F}$ & 2 & 0.00 & 0.00 & 0.00 & 0.00 & 0.00 & 0.00 & 0.00 & 0.00 & 0.00 & $\begin{array}{l}0.00 \\
0.00\end{array}$ & 0.00 & 0.10 & 0.00 & 0.00 & 0.76 & 0.00 & - & \\
\hline $\mathrm{F}$ & 3 & 0.00 & 0.00 & 0.00 & 0.00 & 0.00 & 0.00 & 0.00 & 0.00 & 0.00 & 0.00 & 0.00 & 0.04 & 0.00 & 0.00 & 0.87 & $\begin{array}{l}0.00 \\
\end{array}$ & 0.53 & - \\
\hline & & $\overline{\text { ograp }}$ & & & & & & & & & & & & & & & & & \\
\hline & & $\mathrm{A}$ & Nortl & ern $\mathrm{E}$ & U-15 & & & & & & & D & Trans & sition & countri & es \& & South & America & \\
\hline & & B & Soutl & ern $\mathrm{E}$ & U-15 & & & & & & & $\mathrm{E}$ & Othe & adva & nced c & ountri & & & \\
\hline & & $\mathrm{C}$ & Non- & $\mathrm{EU} \mathrm{N}$ & rthwe & stern E & urope & & & & & $\mathrm{F}$ & Devel & loping & count & & & & \\
\hline & & ensity & & & & & & & & & & & & & & & & & \\
\hline & & 1 & High- & techn & $\log y$ i & ntensiv & e and & prima & y pro & ucts & & & & & & & & & \\
\hline & & 2 & Hum & n-cap & ital in & ensive & and $\mathrm{r}$ & atural & resour & ce int & nsive & roduct & & & & & & & \\
\hline & & 3 & Unsk & lled-l & bor in & tensive & prod & & & & & & & & & & & & \\
\hline
\end{tabular}

The empirical evidence presented in this section shows that the use of the country of origin of imports as a proxy for the factor intensity of the imported goods is too general, since both the origin of imports, in terms of proximity and the level of development, and the factor intensity turn out to be associated with firm-level productivity, but not necessarily follow the same patterns. This shows that the relationship between importing and productivity is shaped simultaneously by all the dimensions of imports identified in section 1, that is, distance, the level of development of the source country and the type of product imported. As Keller (2004) argues, there is no such thing as a global pool of technology, since geography still turns out to play an important role in the diffusion of technologies, for which importing is proven to be a relevant vehicle. The empirical findings align with this argument. Illustrative for this is that high-tech imports from nearby EU-15 have a significantly more beneficial effect on productivity than do high-tech imports from advanced countries outside Europe like the U.S. or Japan. Miroudot et al. (2009) present empirical evidence showing that trade flows of intermediate inputs are more sensitive to trade costs associated with e.g. distance than is trade in final goods. This aligns with our findings showing that the pro- 
ductivity premium of importing is negatively correlated with distance, and provides preliminary evidence for the hypothesis that unskilled labor intensive imports and imports from developing regions contain a relatively large fraction of final goods, as opposed to imports from nearby economies which contain a larger fraction of intermediate inputs providing a more generous source for productivity gains.

\section{Conclusion and discussion}

Combining three comprehensive data sets covering Dutch firms over the years 2002-2008 we investigate the relationship between imports and firm-level productivity. We start by confirming that the productivity ranking by trade status of Dutch firms in increasing order of productivity is: non-traders, importers, exporters, and two-way traders, which is in line with the findings of earlier research regarding other advanced countries. Our analysis subsequently clearly distinguishes between the geographic dimension of the imports (where are the imports from), the goods dimension of the imports (what is imported), and the extensive dimension of the imports (from how many countries and product markets is being imported).

First, our empirical evidence shows that the use of the country of origin of imports as a proxy for the factor intensity, as is frequently done in the literature, is too general, since both the origin of imports and the factor intensity of imported goods turn out to be associated with firm-level productivity. The analysis shows that distance and the level of development of the origin economy are factors affecting the diffusion of efficiency gains embodied in imported goods, indicating that geography still plays an important role in this process. Illustrative for this finding is that technology intensive imports from nearby EU-15 countries are significantly more positively associated with firm-level productivity than are technology intensive imports from advanced countries outside Europe, like the U.S. or Japan. The observed premia patterns are comparable for manufacturing and wholesale \& retail trading sectors, but are generally more pronounced in trading sectors.

Second, our findings show that productivity generally decreases in the share of unskilled-labor intensive imports and rises in the share of technology intensive and primary products. We also show that the geographic-intensity markets are largely unique and cannot be lumped together. We are now able to answer the question raised in the introduction to this paper whether, from a productivity point of view, it is better to import (a) textiles from Germany, (b) cutlery from Italy, or (c) tools from Tanzania? The point estimates in table 6 , column 6 , provide the following order in terms of rising productivity: 
$\mathrm{c}-\mathrm{a}-\mathrm{b}$, but note that the difference between $\mathrm{a}$ and $\mathrm{b}$ is not statistically significant (see table 7).

Third, we show that dispersion, that is a diversified import portfolio in terms of the number of geographical intensity markets on which the firm is active, is positively associated with firm-level productivity. Our findings provide support for the theoretical argument that the fixed cost of importing are market-specific. Adding a new market, either in geographical terms or in terms of product type, to the import portfolio implies incurring this fixed cost again. Note that productivity depends positively on imports within the EU-15, irrespective of the type of product being imported. A possible explanation for this phenomenon is that firms highly focused on imports from nearby countries are an integrated element of a value chain, enabling them to incur efficiency gains.

The empirical evidence presented in this paper thus does not favor the hypothesis that the fixed and variable costs of importing are higher for imports from regions far away or from 'difficult' regions. The nature of the products being imported from these regions could provide an explanation for this, namely that imports from developing countries tend to contain a larger fraction of final goods, compared to imports from advanced countries which contain a larger fraction of intermediate inputs. The potential for incurring productivity and efficiency gains is thought to be larger for intermediate goods imports than for imports of final goods or goods predestined for re-exporting. This suggests that unskilled labor intensive imports contain a relatively large fraction of final goods. In addition, existing empirical evidence, suggesting that trade flows of intermediate inputs are more sensitive to trade costs associated with e.g. distance than is trade in final goods, could explain the pattern of productivity premia observed in our analysis.

Some suggested avenues for further research follow naturally from the preceding discussion and mainly include deeper investigation of the impact of the characteristics of imports on firm-level productivity by accounting for additional dimensions of imports along the lines of capital goods, intermediate goods and final goods. The product classification in terms of broad economic categories (BEC) provided by the United Nations could provide a useful starting point to this purpose. In addition, the role of goods imports destined for re-exporting in the relationship between imports and productivity is not yet well understood. Finally, the direction of causality between importing and productivity also needs to be analyzed more closely along the different dimensions (geography, intensity, and dispersion). That is, selfselection into importing and potential productivity gains emanating from learning-by-importing could crucially hinge on the underlying characteristics of the imported goods. 


\section{A Appendix}

Table 8: Productivity premia of Dutch firms (pooled OLS, 2002-2008)

\begin{tabular}{|c|c|c|c|c|c|c|}
\hline & all firms & $\begin{array}{l}\text { tal factor produ } \\
\text { manufacturing }\end{array}$ & $\begin{array}{l}\text { tivity } \\
\text { wholesale and } \\
\text { retail trade }\end{array}$ & all firms & $\begin{array}{l}\text { labor producti } \\
\text { manufacturing }\end{array}$ & $\begin{array}{l}\text { ty } \\
\text { wholesale and } \\
\text { retail trade }\end{array}$ \\
\hline \multicolumn{7}{|l|}{ trade dummies } \\
\hline non-trader & reference & reference & reference & reference & reference & reference \\
\hline only imports & $\begin{array}{c}0.113^{* * *} \\
(40.95)\end{array}$ & $\begin{array}{c}0.077^{* * *} \\
(18.72)\end{array}$ & $\begin{array}{c}0.135^{* * *} \\
(37.04)\end{array}$ & $\begin{array}{c}0.205^{* * *} \\
(65.74)\end{array}$ & $\begin{array}{c}0.166^{* * *} \\
(35.99)\end{array}$ & $\begin{array}{c}0.226^{* * *} \\
(55.22)\end{array}$ \\
\hline only exports & $\begin{array}{c}0.175^{* * *} \\
(33.33)\end{array}$ & $\begin{array}{c}0.135^{* * *} \\
(18.80)\end{array}$ & $\begin{array}{c}0.213^{* * *} \\
(28.46)\end{array}$ & $\begin{array}{c}0.273^{\text {*** }} \\
(46.46)\end{array}$ & $\begin{array}{c}0.228^{* * *} \\
(28.55)\end{array}$ & $\begin{array}{c}0.317^{* * *} \\
(37.74)\end{array}$ \\
\hline two-way trader & $\begin{array}{l}0.330^{* * *} \\
(105.10)\end{array}$ & $\begin{array}{c}0.230^{* * *} \\
(49.54)\end{array}$ & $\begin{array}{c}0.372^{* * *} \\
(89.35)\end{array}$ & $\begin{array}{l}0.470^{* * *} \\
(134.48)\end{array}$ & $\begin{array}{c}0.346^{* * *} \\
(66.87)\end{array}$ & $\begin{array}{l}0.514^{* * *} \\
(110.96)\end{array}$ \\
\hline \multicolumn{7}{|l|}{ control variables } \\
\hline domestically controlled & reference & reference & reference & reference & reference & reference \\
\hline foreign controlled & $\begin{array}{c}0.271^{* * *} \\
(31.43)\end{array}$ & $\begin{array}{c}0.153^{* * *} \\
(11.31)\end{array}$ & $\begin{array}{c}0.327^{* * *} \\
(29.91)\end{array}$ & $\begin{array}{c}0.235^{* * *} \\
(25.33)\end{array}$ & $\begin{array}{c}0.155^{* * *} \\
(10.36)\end{array}$ & $\begin{array}{c}0.247^{* * *} \\
(21.08)\end{array}$ \\
\hline firm size (fte, log) & $\begin{array}{l}0.274^{* * *} \\
(332.63)\end{array}$ & $\begin{array}{l}0.252^{* * *} \\
(245.74)\end{array}$ & $\begin{array}{l}0.313^{* * *} \\
(223.96)\end{array}$ & $\begin{array}{l}0.128^{* * *} \\
(137.80)\end{array}$ & $\begin{array}{c}0.091^{* * * *} \\
(79.51)\end{array}$ & $\begin{array}{l}0.189^{* * *} \\
(119.78)\end{array}$ \\
\hline No. of observations & $1,035,534$ & 589,782 & 445,752 & $1,080,245$ & 614,041 & 466,204 \\
\hline$a d j . R^{2}$ & 0.190 & 0.211 & 0.176 & 0.105 & 0.111 & 0.108 \\
\hline
\end{tabular}

Notes: All regressions include year, sector and region fixed effects. $t$ statistics in parentheses. ${ }^{*} p<0.05,{ }^{* *} p<0.01,{ }^{* * *}$ $p<0.001$

Table 9: Regional aggregation of origin countries (description)

\begin{tabular}{ll}
\hline region & remarks \\
\hline neighboring countries & Germany and Belgium \\
Northern EU15 & Luxembourg, United Kingdom, Ireland, Denmark, Finland, Sweden, Austria \\
Southern EU15 & France, Greece, Italy, Portugal and Spain \\
non-EU Northwestern Europe & Norway, Switzerland and Iceland, \\
rest of EU & EU27 except EU15 \\
rest of Europe & includes Russia and non-EU Central and Eastern Europe \\
Middle East and North Africa & includes Turkey and Israel \\
Sub-Sahara Africa & includes South Africa \\
advanced Asia* & Japan, South Korea, Singapore, Hong Kong, Taiwan, Brunei Darussalam and Macao \\
developing Asia* & Asia and Pacific except advanced Asia \\
Australia and New Zealand & except Pacific \\
North America & includes United States and Canada \\
Latin America and the Caribbean & includes Brazil and Mexico \\
\hline
\end{tabular}

${ }^{*}$ The advanced Asian countries are identified by GDP per capita levels of at least $\$ 25,000$ (2008 PPP-values in constant 2005\$). 
Table 10: Matrix of bilateral significance of estimated productivity premia by region (table 2 , column 2 )

\begin{tabular}{|c|c|c|c|c|c|c|c|}
\hline & $\begin{array}{l}\text { neigh. } \\
\text { count. }\end{array}$ & $\begin{array}{l}\text { North. } \\
\text { EU-15 }\end{array}$ & $\begin{array}{l}\text { South. } \\
\text { EU-15 }\end{array}$ & $\begin{array}{c}\text { non-EU } \\
\text { N-W Eur. }\end{array}$ & $\begin{array}{l}\text { Aus. } \\
\& \text { NZl }\end{array}$ & $\begin{array}{l}\text { adv. } \\
\text { Asia }\end{array}$ & $\begin{array}{l}\text { North } \\
\text { Am. }\end{array}$ \\
\hline neighboring countries & - & & & & & & \\
\hline Northern EU-15 & 0.044 & - & & & & & \\
\hline 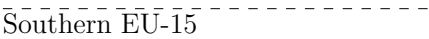 & ${ }^{-} 0 . \overline{0} 00^{-}$ & $\overline{0} . \overline{0} 0 \overline{0}$ & - & & & & \\
\hline non-E $\overline{\mathrm{E}} \overline{\mathrm{U}}^{-}$Northwestern Europe & 0.000 & $\overline{0} . \overline{0} 0 \overline{0}$ & $0 . \overline{0} 0 \overline{3}^{-}$ & $-\ldots$ & & & \\
\hline 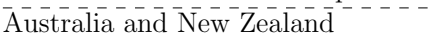 & ${ }^{-} 0 . \overline{0} 00^{-}$ & $\overline{0} . \overline{0} 0 \overline{0}^{-}$ & $0 . \overline{0} 0 \overline{1}-$ & $\overline{0.0 \overline{4}} \overline{9}$ & - & & \\
\hline advanced Asia & 0.000 & 0.000 & 0.000 & 0.000 & 0.601 & - & \\
\hline North America & 0.000 & 0.000 & 0.000 & 0.000 & 0.257 & 0.199 & - \\
\hline$\overline{\text { Latin }} \overline{\text { America and the Caribean }}$ - & ${ }^{-} 0 . \overline{0} 00^{-}$ & $\overline{0} . \overline{0} 0 \overline{0}$ & $0 . \overline{0} 00^{-}$ & $\overline{0.00} \overline{0}$ & $\overline{0} . \overline{2} \overline{8} 9^{-}$ & $0 . \overline{36} \overline{7}-$ & $\overline{0} . \overline{8} \overline{4} \overline{4}$ \\
\hline rest of EU & 0.000 & 0.000 & 0.000 & 0.000 & 0.777 & 0.733 & 0.174 \\
\hline rest of Europe & 0.000 & 0.000 & 0.000 & 0.000 & 0.095 & 0.085 & 0.247 \\
\hline sub-Sahara Africa & $0.000^{-}$ & $\overline{0} . \overline{0} 0 \overline{0}$ & $0 . \overline{0} 00^{-}$ & $\overline{0} . \overline{0} \overline{0}$ & $\overline{0} . \overline{0} \overline{1} 2^{-}$ & $0.00 \overline{5}$ & $\overline{0} . \overline{0} \overline{1} \overline{8}$ \\
\hline developing Asia & 0.000 & 0.000 & 0.000 & 0.000 & 0.000 & 0.000 & 0.000 \\
\hline \multirow[t]{2}{*}{ Middle East and North Africa } & 0.000 & 0.000 & 0.000 & 0.000 & 0.000 & 0.000 & 0.000 \\
\hline & $\begin{array}{l}\text { rest } \\
\text { of } \mathrm{EU}\end{array}$ & $\begin{array}{l}\text { rest } \\
\text { Eur. }\end{array}$ & $\begin{array}{l}\text { Lat. Am. of } \\
\text { \& Car. }\end{array}$ & $\begin{array}{c}\text { sub-Sah. } \\
\text { Afr. }\end{array}$ & $\begin{array}{l}\text { dev. } \\
\text { Asia }\end{array}$ & \multicolumn{2}{|l|}{$\begin{array}{c}\text { M-East } \\
\& \text { N. Afr. }\end{array}$} \\
\hline Latin America and the Caribbean & - & & & & & & \\
\hline rest of EU & 0.286 & - & & & & & \\
\hline rest of Europe & 0.439 & 0.071 & - & & & & \\
\hline sub-Sahara África & $0 . \overline{077} \overline{7}^{-}$ & $\overline{0} . \overline{0} \overline{4}$ & $0 . \overline{3} 2 \overline{3}-$ & - & & & \\
\hline developing Asia & 0.000 & 0.000 & 0.007 & 0.231 & - & & \\
\hline Middle East and North Africa & 0.000 & 0.000 & 0.002 & 0.092 & 0.251 & - & \\
\hline
\end{tabular}

Note: Values represent bilateral $p$-values obtained from regressions of firm-level productivity on import shares by region with varying baseline regions. The dashed lines identify the aggregation into six regions for the analysis in section 7 .

Table 11: Matrix of bilateral significance of estimated productivity premia by factor intensity (table 4, column 2)

\begin{tabular}{|c|c|c|c|c|c|}
\hline & $\begin{array}{l}\text { primary } \\
\text { products }\end{array}$ & $\begin{array}{l}\text { high-tech } \\
\text { products }\end{array}$ & $\begin{array}{c}\text { natural resource } \\
\text { intensive }\end{array}$ & $\begin{array}{c}\text { human capital } \\
\text { intensive }\end{array}$ & $\begin{array}{c}\text { unskilled labor } \\
\text { intensive }\end{array}$ \\
\hline primary products & - & & & & \\
\hline high-tech products & 0.928 & - & & & \\
\hline natural resource intensive & $\overline{0} . \overline{0} 00^{-}$ & $\overline{0} . \overline{0} \overline{0}{ }^{-}$ & - & & \\
\hline human capital intensive & 0.000 & 0.000 & 0.752 & - & \\
\hline unskille $\bar{d}$ labor intensive & $0 . \overline{0} 00^{-}$ & $\overline{0} . \overline{0} 00^{-}$ & 0.000 & $0 . \overline{0} 00$ & - \\
\hline
\end{tabular}

Note: Values represent bilateral $p$-values obtained from regressions of firm-level productivity on import shares by product group with varying baseline products. The dashed lines identify the aggregation into three product groups for the analysis in section 7 . 
Table 12: Import origin, factor intensity, degree of dispersion and total factor productivity (pooled OLS, 2002-2008)

\begin{tabular}{|c|c|c|c|c|c|c|}
\hline & \multicolumn{3}{|c|}{$\begin{array}{l}\text { manufacturing } \\
\text { sectors }\end{array}$} & \multicolumn{3}{|c|}{$\begin{array}{l}\text { wholesale and } \\
\text { retail trading }\end{array}$} \\
\hline & (1) & & (3) & (4) & & (6) \\
\hline \multicolumn{7}{|l|}{ import shares by geographic import market } \\
\hline Northern EU-15 (incl. neighboring countries) & $0.247^{* * *}$ & & & $0.419^{* * *}$ & & \\
\hline Southern EU-15 & 0.103 & & & $0.300^{* * *}$ & & \\
\hline non-EU Northwestern Europe & $0.0786^{* *}$ & & & $0.161^{* * *}$ & & \\
\hline transition countries \& South America & 0.0201 & & & 0.00546 & & \\
\hline other advanced countries & reference & & & reference & & \\
\hline developing countries & $-0.0694^{* *}$ & & & $-0.160^{* * *}$ & & \\
\hline \multicolumn{7}{|l|}{ import shares by intensity market } \\
\hline high-tech \& primary products & & 0.001 & & & $0.142^{* * *}$ & \\
\hline human capital \& natural resource intensive & & reference & & & reference & \\
\hline unskilled labor intensive & & $-0.100^{* * *}$ & & & $-0.119^{* * *}$ & \\
\hline \multicolumn{7}{|l|}{ import shares by geographic intensity market } \\
\hline \multicolumn{7}{|l|}{ Northern EU-15 incl. neighboring countries } \\
\hline high-tech \& primary products & & & $0.244^{* * *}$ & & & $0.536^{* * *}$ \\
\hline human capital \& natural resource intensive & & & $0.317^{* * *}$ & & & $0.511^{* * *}$ \\
\hline unskilled labor intensive & & & $0.249^{* * *}$ & & & $0.403^{* * *}$ \\
\hline \multicolumn{7}{|l|}{ Southern EU-15 } \\
\hline high-tech \& primary products & & & 0.127 & & & $0.452^{* * *}$ \\
\hline human capital \& natural resource intensive & & & $0.242^{* *}$ & & & $0.439^{* * *}$ \\
\hline unskilled labor intensive & & & -0.0767 & & & $0.291^{* * *}$ \\
\hline \multicolumn{7}{|l|}{ non-EU Northwestern Europe } \\
\hline high-tech \& primary products & & & $0.120^{* *}$ & & & $0.306^{* * *}$ \\
\hline human capital \& natural resource intensive & & & 0.0523 & & & $0.194^{* * *}$ \\
\hline unskilled labor intensive & & & $0.166^{*}$ & & & $0.144^{*}$ \\
\hline \multicolumn{7}{|l|}{ transition countries $\&$ South America } \\
\hline high-tech \& primary products & & & 0.0195 & & & $0.147^{* *}$ \\
\hline human capital \& natural resource intensive & & & $0.115^{*}$ & & & 0.102 \\
\hline unskilled labor intensive & & & -0.0543 & & & -0.0386 \\
\hline \multicolumn{7}{|l|}{ other advanced countries } \\
\hline high-tech \& primary products & & & 0.0441 & & & $0.202^{* * *}$ \\
\hline human capital \& natural resource intensive & & & reference & & & reference \\
\hline unskilled labor intensive & & & -0.026 & & & $-0.187^{* * *}$ \\
\hline \multicolumn{7}{|l|}{ developing countries } \\
\hline high-tech \& primary products & & & 0.000378 & & & 0.0179 \\
\hline human capital \& natural resource intensive & & & -0.0443 & & & $-0.170^{* * *}$ \\
\hline unskilled labor intensive & & & $-0.132^{* *}$ & & & $-0.133^{* * *}$ \\
\hline \multicolumn{7}{|l|}{ degree of dispersion of imports } \\
\hline number of geographical markets (log) & $0.0626^{* * *}$ & & & $0.124^{* * *}$ & & \\
\hline number of intensity markets (log) & & $0.0503^{*}$ & & & $0.0764^{* * *}$ & \\
\hline number of geographical intensity markets (log) & & & $0.0362^{*}$ & & & $0.0913^{* * *}$ \\
\hline \multicolumn{7}{|l|}{ control variables } \\
\hline non-exporter & reference & reference & reference & reference & reference & reference \\
\hline exporter & $0.148^{* * *}$ & $0.206^{* * *}$ & $0.149^{* * *}$ & $0.201^{* * *}$ & $0.304^{* * *}$ & $0.189^{* * *}$ \\
\hline domestically controlled & reference & reference & reference & reference & reference & reference \\
\hline foreign controlled & $0.126^{* * *}$ & $0.147^{* * *}$ & $0.129^{* * *}$ & $0.271^{* * *}$ & $0.342^{* * *}$ & $0.254^{* * *}$ \\
\hline firm size (FTE, log) & $0.202^{* * *}$ & $0.223^{* * *}$ & $0.203^{* * *}$ & $0.233^{* * *}$ & $0.299^{* * *}$ & $0.230^{* * *}$ \\
\hline No. of observations & 8,869 & 8,869 & 8,869 & 21,009 & 21,009 & 21,009 \\
\hline$R^{2}$ & 0.284 & 0.275 & 0.286 & 0.266 & 0.239 & 0.272 \\
\hline
\end{tabular}




\section{References}

Acharya, R. C., and W. Keller. 2009. Technology transfer through imports. Canadian Journal of Economics 42 (4): 1411-1448.

Amiti, M., and J. Konings. 2007. Trade liberalization, intermediate inputs, and productivity: Evidence from indonesia. The American Economic Review 97 (5): 1611-1638.

Bas, M., and V. Strauss-Kahn. 2010. Does importing more inputs raise exports? firm level evidence from france, MPRA Paper No. 27315, University of Munich.

Bernard, A. B., J. B. Jensen, S. J. Redding, and P. K. Schott. 2007. Firms in international trade. The Journal of Economic Perspectives 21 (3): 105130.

Castellani, D., F. Serti, and C. Tomasi. 2010. Firms in international trade: Importers $\breve{S}$ and exporters $\breve{S}$ heterogeneity in italian manufacturing industry. The World Economy 33 (3): 424-457.

Coe, D. T., and E. Helpman. 1995. International r\&d spillovers. European Economic Review 39 (5): 859-887.

Coe, D. T., E. Helpman, and A. Hoffmaister. 1997. North-south r\&d spillovers. The Economic Journal 107 (440): 134-149.

Creusen, H., and A. Lejour. 2011. Uncertainty and the export decisions of dutch firms, CPB Discussion Paper No. 183, CPB Netherlands Bureau for Economic Policy Analyis.

Girma, S., H. Görg, and E. Strobl. 2004. Exports, international investment, and plant performance: evidence from a non-parametric test. Economics Letters 83 (3): 317-324.

Hagemejer, J., and M. Kolasa. 2011. Internationalisation and economic performance of enterprises: Evidence from polish firm-level data. The World Economy 34 (1): 74-100.

Keller, W. 2004. International technology diffusion. Journal of Economic Literature 42 (3): 752-782. http://www.jstor.org/stable/3217250.

Levinsohn, James, and Amil Petrin. 2003. Estimating production functions using inputs to control for unobservables. The Review of Economic Studies 70 (2): 317-341. http://www.jstor.org/stable/3648636. 
Lööf, H., and M. Andersson. 2010. Imports, productivity and origin markets: The role of knowledge-intensive economies. The World Economy 33 (3): 458-481.

Melitz, M. J., and D. Trefler. 2012. Gains from trade when firms matter. Journal of Economic Perspectives 26 (2): 91-118. doi:10.1257/jep.26.2.91. http://www.aeaweb.org/articles.php?doi=10.1257/jep.26.2.91.

Miroudot, S., R. Lanz, and A. Ragoussis. 2009. Trade in intermediate goods and services, OECD Trade Policy Working Papers No. 93, OECD Publishing.

Muûls, M., and M. Pisu. 2009. Imports and exports at the level of the firm: Evidence from belgium. The World Economy 32 (5): 692-734.

Serti, F., and C. Tomasi. 2009. Self-selection along different export and import markets, LEM Papers Series LEM Papers Series No. 18, Laboratory of Economics and Management.

Silva, A., O. Afonso, and A. P. Africano. 2012. Which manufacturing firms learn by exporting? The Journal of International Trade \& Economic Development 21 (6): 773-805. doi:10.1080/09638199.2010.534811. http://www.tandfonline.com/doi/abs/10.1080/09638199.2010.534811.

Van den Berg, M. 2013. Imports, productivity and firm size: firm-level evidence from the netherlands. mimeo.

Van Marrewijk, C. 2002. International trade \& the world economy. Oxford University Press.

Vogel, A., and J. Wagner. 2010. Higher productivity in importing german manufacturing firms: self-selection, learning from importing, or both? Review of World Economics 145 (4): 641-665.

Wagner, J. 2012. International trade and firm performance: a survey of empirical studies since 2006. Review of World Economics 148: 235-267. 10.1007/s10290-011-0116-8. http://dx.doi.org/10.1007/s10290011-0116-8. 